\title{
Reclassification of the Angraecum-alliance (Orchidaceae, Vandoideae) based on molecular and morphological data
}

\author{
Dariusz L. Szlachetko*, Piotr Tukałło, Joanna Mytnik-Ejsmont \\ \& Elżbieta Grochocka
}

Department of Plant Taxonomy and Nature Conservation, University of Gdańsk, Wita Stwosza 59, 80-308 Gdańsk, Poland

* corresponding author (e-mail: dariusz.szlachetko@gmail.com)

\begin{abstract}
Results of molecular analysis compared with morphological studies were used for reclassification of the Angraecumalliance (Orchidaceae). For the purpose of this study we sequenced the ITS region (ITS1-5.8S-ITS2) of nrDNA representing nuclear genome and the plastid region trnL-F (including intron of trnL gene and trnL-trnF intergenic spacer). The ITS matrix includes 97 samples representing 86 species and the trnL-F matrix includes 94 samples representing 86 species. We focus mainly on the genus Angraecum, however the other genera of Angraecinae are also included (Aeranthes, Campylocentrum, Dendrophylax, Cryptopus, Calyptrochilum, Lemurorchis, Jumellea, Neobathiea, Oeonia, Oeoniella, Sobennikoffia). Additional 43 sequences, including an outgroup (Polystachya modesta) and other representatives of the subtribes Aeridinae (Aerides) and Aerangidinae (Aerangis, Angraecopsis, Erasanthe, Solenangis), were obtained from NCBI resources. Bayesian analysis using MrBayes 3.1.2 on the combined ITS/trnL-F matrix were performed. The monophyly of Angraecinae with an inclusion of Aerangidinae is highly supported by both methods (93 BP/100 PP). The Angraecoid taxa formed two well supported clades, namely clade I (89 BP/100 PP) and clade II (84 BP/100 PP). New classification based on both molecular and classical taxonomy studies is presented including a key to the genera. The subtribe Angraecinae includes 36 genera, 18 of them, included within Angraecum by different authors so far, are treated here. Five new genera are described: Eichlerangraecum, Hermansia, Lesliegraecum, Pectianriella and Rudolfangraecum. Ten sections of Angraecum are raised to the generic status.
\end{abstract}

Key words: Angraecum, ITS, molecular phylogeny, new genus, taxonomy, trnL-F

\section{Introduction}

Orchids of the tribe Vandeae Lindl. have usually been divided into three subtribes: Aeridinae Pfitz. (=Sarcanthinae Benth.), Angraecinae Summerh. and Aerangidinae Summerh. The most important reason for dividing Vandeae was the geographical criterion. The great majority of Aeridinae occur in south-eastern Asia and Australasia, Angraecinae are found in Africa, Madagascar and South and Central America, whereas Aerangidinae occur only in Africa and Madagascar. Dressler (1993) suggested an independent evolution of a leafless habit with photosynthetic roots in Asia, Africa and tropical America. He also proposed that this habit probably evolved more than once in Asia and may have done so in Africa.

Vandeae were first defined by Lindley (1835) who grouped the members of the group basing on the presence of distinct "caudicles" of the pollinarium. In addition to Vandeae sensu Dressler (1993; e.g. Vanda and Angraecum), a significant part (40\%) of Lindley's group comprises tropical American taxa that are now placed in Maxillarieae.

Garay $(1960,1972)$ reinstated tribe Vandeae based on the presence of an incumbent anther, porrect rostellum, and well-developed stipes. Vandeae sensu Garay included tropical American subtribes: Cyrtopodiinae Benth., Zygopetalinae Schltr. and Oncidiinae Benth. as well as Vandinae Rchb.f. (Garay 1972). 
The subtribes Angraecinae and Aerangidinae were described by Summerhayes in 1966. He officially recognized these two groups as the subtribes of Vandeae which were earlier separated by Schlechter (1918), according to the structure of the rostellum. In Angraecinae, the rostellum is deeply divided and in Aerangidinae is elongate and beak-like (Dressler 1993). Morphologically, the members of these two subtribes have similar vegetative and floral features and are often referred to collectively as "angraecoids". Chromosome counts were made by Jones (1967) and showed cytological support for the subdivision of the angrecoid orchids (Angraecinae and Aerangidinae) on the morphological basis and revealed the chromosome number for Angraecinae $n=19$ and for Aerangidinae $\mathrm{n}=25$. Arends et al. (1980) and Arends and Van der Laan's (1983) in their preliminary karyological studies questioned the previous division of the African Vandeae. These authors established four groups: the first one with a short rostellum and $n=19$ (Aeranthes Lindl., Cryptopus Lindl., Jumella Schlecht. and some species of Angraecum Bory), the second one with a short rostellum and $n=21,23,24,25$ (some species of Angraecum), the third one with a beak-like rostellum and $n=19$ (Calyptrochilum Kraenzl.) and the fourth one with a beak-like rostellum and $n=23$ to 27 (most of Aerangidinae).

Dressler (1981) elevated units of the original tribe Epidendreae Lindl. delimited by Dressler and Dodson (1960) to form two subfamilies: Epidendroideae Lindl. ex Endl. and Vandoideae Endl.. Although Vandoideae have long been recognized (at various taxonomic levels) on the basis of floral morphology, there were few consistent characters to delimit Vandoideae from Epidendroideae. Dressler admitted that the only clear character delimiting these two subfamilies was anther development and, several years later (1989), he reinstated the members of Vandoideae into a broadly defined Epidendroideae, much like his original systematic treatment with Dodson (Dressler \& Dodson 1960). In his classification system, Vandeae formed a well-defined group of orchids splitted into three subtribes: Sarcanthinae, Angraecinae and Aerangidinae.

Dressler (1993) united Vandeae with Dendrobieae and Podochileae in a dendrobioid subclade of Epidendroideae and replaced the illegitimate subtribal name Sarcanthinae (Bentham 1881) with Aeridinae.

Szlachetko in 1995 divided Vandeae into 14 subtibes (Vandinae Rchb.f., Deceptorinae Szlach., Phalaenopsidinae Szlach., Gastrochilinae Szlach., Aeridinae, Diplocentrinae Szlach., Pelatantheriinae Szlach., Taeniophyllinae Szlach., Bolusiellinae Szlach., Listrostachyinae Szlach., Calyptrochilinae Szlach., Aerangidinae, Rhaesteriinae Szlach., Angraecinae) according to the rostellum and pollinarium structure. Basing on the gynostemium structure, he precluded possibility that
Dendrobieae and Podochileae are closely related to Vandeae as Dressler (1993) proposed.

A morphological study of Orchidaceae based on results of cladistic analysis was carried out by Freudenstein and Rasmussen (1999). According to their work, Vandeae form a monophyletic tribe with several synapomorphies: isodiametric exodermal cell shape, monopodial growth habit, spherical stegmata and seeds with laterally compressed walls. Beacuse of the reduction of four pollinia to two, Aerangis and Angraecum were united and formed a sister clade to a paraphyletic grade of Aeridinae (Acampe and Phalaenopsis). Freudenstein and Rasmussen (1999) also indicate a sister relationship with Polystachyinae Schltr.

In the classification of Orchidaceae presented by Chase et al. (2003), Vandeae form a monophyletic tribe within a large polytomy of advanced epidendroid groups (Cymbidieae and Agrostophyllinae Szlach.) and include the sympodial subtribe Polystachyinae. The sister relationship of Vandeae sensu Dressler (1993) and Polystachyinae is well-supported by the analyses of Cameron (2001) as well as van den Berg et al. (2005).

According to the results of molecular and morphological studies conducted by Carlsward et al. (2006), the monopodial Vandeae form a strongly supported clade ( $>90 \mathrm{BP})$. Within this clade, Aeridinae also form a wellsupported clade with $>90 \mathrm{BP}$ in all analyses. Carlsward et al. (2006) suggested that Aerangidinae and Angraecinae s. str. should be classified within Angraecinae sensu lato. The authors consider that individually these two subtribes are polyphyletic but together they form a well-supported monophyletic clade in all molecular analyses. Within Angraecinae, a large clade of primarily Madagascan taxa (93 BP) is sister to an unresolved clade of the Old and New World angraecoids (95 BP). The chromosome number common in many Aerangidinae $n=25$ suggests some affinities between Aerangidinae (primarily African) and the African species of Angraecum.

Angraecinae is a large and diverse group restricted mainly to Paleotropics. Garay (1973) distinguished 15 African and four American genera within this subtribe. Szlachetko (1995) transferred two genera (Angraecopsis Kraenzl. and Cribbia Senghas) to Angraecinae from Aerangidinae, increasing the number of African genera within the subtribe to 19. Carlsward et al. (2003) included Harrisella Fawc. \& Rendle and Polyradicion Garay into the genus Campylocentrum Benth., reducing the number of American genera from four to two. Stewart et al. (2006) accepted the Garay's (1973) classification of Angraecum, and Chase's (2003) classification of the subtribes.

Most of Angraecinae were initially included within the genus Angraecum until Schlechter (1918) reviewed the entire group and divided the genus into six sections. In 1925, he increased the number of the sections to thirteen, after acquaintance with the Perrier's orchid 
collection from Madagascar. The taxonomic revision of the genus was presented by Garay (1973), who distinguished nineteen sections within Angraecum.

The representatives of Angraecinae are monopodial, epiphytic or lithophytic plants with a wide variety of habits, from specimens with elongate stems and welldeveloped leaves to those with reduced stems and small scale leaves. They are pollinated mostly by moths in accordance with the structure of flower. The subtribe Angraecinae is well characterized by a structure of the rostellum which is deeply notched, dome-like, wide and short. Tegula is single or double, usually small, sometimes papillate near the attachment of the pollinia. Viscidium is single or double, oblong to elliptic, as large as or smaller than the tegula (Szlachetko 2003).

Angraecum, the most species rich genus of the subtribe, includes about 200 species, distributed in tropical Africa and Madagascar with one species occurring in Sri Lanka and the Seychelles (Angraecum zeylanicum Lindl.). Most of the taxa occur in Madagascar, about 50 species have been recorded from the mainland of Africa (Stewart et al. 2006). The representatives of Angraecum are monopodial herbs of various size. Stems are short or elongate, branching or unbranched. Leaves are dorsiventrally flattened or laterally compressed, imbricating basally or well-spaced, thin-textured or fleshy, coriaceous. Inflorescence is erect or pendent, single- to many-flowered. Flowers are tiny to large, resupinate or not. Sepals and petals are similar (one another). Lip is simple, usually entire, furnished with a callus or not, spurred. Gynostemium is short and massive, erect. Stigma is large, deeply concave, elliptic. Anther is incumbent, operculate, dorsiventrally flattened, thin-walled, notched in front. Two pollinia are ellipsoid or obovate, cleft, dorsiventrally flattened. The rostellum is deeply notched, short, dome-like. Double viscidia are oblong, thin, delicate. Double tegulae is linear, delicate, lamellate. In many species single tegula or tegula variously splitted or divided is attached to the single viscidium. The rostellum is deeply notched after removal of pollinaria (Szlachetko 2003).

Phylogenetic relationships of the closely related genera and species within the Angraecum subtribe were presented in Carlsward et al. (2006). The authors analyzed the ITS nrDNA, trnL-F plastid DNA, and matK plastid DNA. The results of these analyses revealed that Angraecum is clearly polyphyletic. The genera Bonniera Cordem., Oeoniella Schltr. and Sobennikoffia Schltr. are embedded within the clade composed primarily of the species of Angraecum.

Because Angraecum is a polyphyletic group and the results of detailed morphological studies support reclassification of the Angraecum alliance, we propose a new classification of Angraecinae and the results of our studies are presented below.

\section{Materials and methods}

\subsection{Molecular markers and taxon sampling}

We collected 56 samples from living specimens representing Angraecum sensu lato and minor angraecoid genera. Leaf samples were obtained from the botanical gardens of Hamburg, Heidelberg, Munich and Wien, our filed trips to New World, Africa and Madagascar as well as from the living collection of the University of Gdańsk. Basing on an availability of the sequence data in GenBank from previous studies (Carlsward et al. 2006), we chose two molecular markers. For the purpose of this study we sequenced the ITS region (ITS1-5.8SITS2) of nrDNA representing nuclear genome and the plastid region $t r n \mathrm{~L}-\mathrm{F}$ (including intron of $t r n \mathrm{~L}$ gene and $t r n \mathrm{~L}-t r n \mathrm{~F}$ intergenic spacer). Additional 43 sequences including an outgroup and other representaives of the subtribes Aeridinae and Aerangidinae were obtained from NCBI resources.

\subsection{DNA extraction}

Total genomic DNA was extracted from 15-20 mg of silica-dried leaves using Genomic Mini AX Plant (A\&A Biotechnology, Gdynia, Poland), following manufacturer protocols. Precooled in $-45^{\circ} \mathrm{C}$ Lysing Matrix A tubes and FastPrep instrument (MP Biomedicals, USA) were used for samples homogenization. Pelleted DNA was then dried overnight and resuspended in $50 \mathrm{ul}$ of dd $\mathrm{H}_{2} \mathrm{O}$ and stored in $4^{\circ} \mathrm{C}$ for further usage.

\subsection{PCR and sequencing}

Amplification and sequencing were carried in Biometra TGradient and Eppendorf Mastercycler thermalcyclers. Polymerase chain reaction (PCR) was carried in a final volume of $25 \mu 1$ using Color Perpetual Taq DNA Polymerase kit (Eurx, Gdansk, Poland) with addition of dimethyl sulfoxide (DMSO) to the final concentration of $5 \%$ per sample.

The ITS region (ITS1-5.8S-ITS2) was amplified using two sets of primers: 17SE and 26SE of Sun et al. (1994). In a few cases, the ITS4 and ITS5 (White et al. 1990) primers were used for the nested PCR technique. The PCR conditions for ITS were adopted from Carlsward et al. (2006): initial denaturation for 6 min in $98^{\circ} \mathrm{C}$, pause at $80^{\circ} \mathrm{C}$, addition of Taq, followed by 33 cycles with $45 \mathrm{sec}$ denaturation in $95^{\circ} \mathrm{C}, 45 \mathrm{sec}$ annealing in $57^{\circ} \mathrm{C}$ (for $\mathrm{AB} 101 / \mathrm{AB} 102$ primer set) or $52^{\circ} \mathrm{C}$ (for ITS4/ITS5 primer set) and 1 min elongation in $72^{\circ} \mathrm{C}$, with a final extension for $7 \mathrm{~min}$ in $72^{\circ} \mathrm{C}$.

For the trnL-F region, primers from Taberlet et al. (1991) were used with PCR condition adopted from Shaw et al. (2007, 'slow and cold'): intial denaturation for $6 \mathrm{~min}$ in $98^{\circ} \mathrm{C}$, pause at $80^{\circ} \mathrm{C}$ - added Taq, followed by 33 cycles with 1 min denaturation in $95^{\circ} \mathrm{C}, 1 \mathrm{~min}$ of annealing in $50^{\circ} \mathrm{C}$ and 4 min of primer extension in 
$65^{\circ} \mathrm{C}$, with a final extension step for $7 \mathrm{~min}$ in $65^{\circ} \mathrm{C}$. Three samples failed to amplify (Angraecum drouhardii, A. crassum, A. montanum).

The PCR products were purified using the High Pure PCR Product Purification Kit (Roche Diagnostic GmbH, Germany) following the manufacturer's protocol. Sequencing reaction was carried using Big Dye terminator v 3.1 chemistry (Applied Biosystems, Inc.) with the same primers used for PCR amplification in a total of 10 $\mu 1$ reaction volume. Cycle sequencing conditions were as follow: 25 cycles each with $15 \mathrm{sec}$ denaturation $\left(94^{\circ} \mathrm{C}\right)$, $5 \mathrm{sec}$ annealing $\left(50^{\circ} \mathrm{C}\right)$ and 4 min elongation $\left(60^{\circ} \mathrm{C}\right)$. The sequencing reaction products were then purified and sequenced on ABI 3720 automated capillary DNA sequencer in the Institute of Biochemistry and Biophysics, Polish Academy of Sciences (Warsaw). Sequences were inspected/edited in Chromas (Technelysium Pty Ltd.) and assembled in AutoAssembler (Applied Biosystems, Inc). All sequences were checked against BLAST (Basic Local Alignment Search Tool) from NCBI for possible fungal or other non-orchid contamination. For both ITS and trnL-F regions, final alignments were done manually in Seaview (Galtier et al. 1996) following the guidelines from Kelchner (2000). Resulting indels were coded manually as additional binary characters following the simple coding method of Simmons and Ochoterena (2000).

\subsection{Parsimony analysis}

We performed a cladistic analysis using Fitch parsimony (Fitch 1971) with PAUP* 4.0b10 (Swofford 2003) and Polystachya modesta designated as a single species outgroup.

Heuristic searches were performed using tree bisection reconnection (TBR) branch swapping, simple sequence addition and maxtrees limit set to 10.000. All characters were equally weighted and gaps were treated as missing data. Internal support for clades was estimated using bootstrap (BP) percentages (Felsenstein $1985)$ with 1.000 bootstrap replicates, simple addition and TBR branch swapping but saving no more than 10 trees per replicate (Salamin et al. 2003). We define boostrap support as weak for values from 50-74, moderate for 75-89 and high for 90-100.

Initially, the ITS and trnL-F matrices were analyzed separately. We used bootstrap trees generated for each region to manually compared them for congruence, following guidelines from Wiens (1998). If there is no conflict, the well-supported clades (bootstrap percentage higher than 74) between the regions, the datasets for each region can be combined into a single matrix. The samples that failed to amplify in one of the regions or were unavailable from NCBI were coded as missing. The combined analysis was performed with the same heuristic search strategies as described above.
We also tested data congruence using the partition homogeneity test in PAUP* version 4.0b10, implementation of ILD (Incongruence length difference) test by Farris et al. (1994). Heuristic searches for the test were performed using 1.000 replicates and an TBR algorithm but saving no more than 10 trees per replicate. Probability values (p) greater than 0.05 were used to identify whether the data sets were not significantly different from each other and could therefore be combined.

\subsection{Bayesian analysis}

We also performed a bayesian analysis using MrBayes 3.1.2 (Ronquist \& Huelsenbeck 2003) on the combined ITS/trnL-F matrix. The generalized model of DNA substitution was calculated using MrModeltest 2.2 (Nylander 2004). The posterior probabilities (PP) of clades were estimated by sampling trees from the PP distribution using Markov chain Monte Carlo simulations. Two parallel runs with four simultaneous chains were executed for 5.000.000 generations with trees sampled every 100 generation. A plot of generations against likelihood scores of the sampled trees was then examined in order to establish "burn-in" required for both runs to converge on a stationary probability value. Burn-in trees were then discarded from the study. The remaining trees were used to calculate a majority-rule consensus tree using "sumt" command in MrBayes.

\section{Results and discussion}

\subsection{ITS}

The ITS matrix includes 97 samples representing 86 species. Considering 867 analyzed aligned sequence positions (799 after excluding indels), 442 were potentially parsimony informative (374 after excluding indels). Heuristic analysis produced +10.000 equally parsimonious trees (trees not shown) with length (L) of 1517 steps, consistency index $(\mathrm{CI})-0.404$, and retention index (RI) -0.747 .

According to the ITS results, monophyly of Angraecine with Aerangidinae against the outgroup and Aeridinae is weakly supported with $50 \mathrm{BP}$. The remaining ingroup taxa form two weakly supported clades. The large clade (56 BP) consists almost entirely of the Malagasy-Mascarene angraecoid species (with representatives on Seychelles and Comoros), with the exception of continental A. conchiferum, A. dives and partially $A$. eburneum. The smaller clade (65 BP) is formed by continental species of Angraecum, N eotropical Angraecinae, minor Malagasy angraecoid genera and representatives of the genus Aerangis (Aerangidinae). However, the resolution within each of these two nodes was weak with rather low to moderate bootstrap support. 


\section{2. $\operatorname{trnL}-\mathrm{F}$}

The trnL-F matrix includes 94 samples representing 86 species with 1905 aligned positions (1010 after exluding indels) of which 649 positions were potentially parsimony informative (588 after exluding indels). Heuristic search produced +10.000 equally parsimonious trees with length (L) of 1127 steps, consistency index (CI) -0.684 , and retention index (RI) of 0.787 (trees not shown). The monophyly of Angraecinae with Aerangis (Aerangidinae) against the outgroup and Aeridinae is moderately suppported with $81 \mathrm{BP}$. Similar to the ITS results, the ingroup taxa form two clades, although, only the smaller clade, consisting of the continental Angraecum species, neotropical and Malagasy Angraecine and three accessions of Aerangis, is moderately supported with $81 \mathrm{BP}$. The resolution and overall bootstrap support was much higher for the trnL-F matrix than ITS.

\subsection{Combined analysis}

The results of partition homogenity test for the nrITS and trnL-F datasets indicate that the partitions were significantly different from random partitions $(\mathrm{p}=0.01)$, thus should not be combined. However, the ILD test can sometimes reveal unreliable results (Dolphin et al. 2000, Reeves et al. 2001) and the observed incongruence can be more likely a result of an insufficient taxon sampling or weak phylogenetic signal and homoplasy (Wendel $\&$ Doyle 1998). Visual inspection of separate bootstrap trees revealed no major conflicting clades with higher bootstrap support $(\mathrm{BP}>75)$. Therefore, we decided to combine both datasets into a single matrix and proceed with a combined analysis. The tree statistics for the combined and separate analysis is summarized in the Table 1.

The combined ITS/trnL-F matrix, representing 98 acessions, consisted of 2770 aligned positions (2639 after excluding indels) with 621 parsimony informative characters (548 excluding indels). Heuristic search resulted in 652 equally parsimonious trees with length (L) of 2736 steps, consistency index (CI) -0.502 and retention index (RI) of 0.740 . An exclusion of the coded indels decreased the overall trees length but also increased the number of resultant trees to 777 . Although we did not observe substantial changes in trees topology after the exclusion of indels, the bootstrap support for major clades was significantly lower than when the indels were included.

The combined analysis resulted in much better resolved trees compared to the separate analysis of each dataset. The Bayesian analysis produced approximately the same tree topology as parsimony. One of the most parsimonious trees annoted with $\mathrm{BP}$ and $\mathrm{PP}$ values is shown in the Fig 1. The monophyly of Angraecinae with an inclusion of Aerangidinae is highly supported by both methods (93 BP/100 PP). The Angraecoid taxa fall into two well supported clades, namely clade I ( 89 BP/100 PP) and clade II (84 BP/100 PP). We cannot indicate, however, any synapomorphy for either of clades.

Clade I contains nearly exclusively the Mascarenian, Malagasy and Malagasy-Mascarenian Angraecum species (with three exceptions described above) and some angraecoid genera (Aeranthes, Bonniera, Jumellea, Lemurorchis, Oeniella and Sobennikoffia) with similar distribution range. Species included in this clade possess both resupinate (Angraecum sesquipedale) and nonresupinate (Angraecum eburneum) flowers, with variously developed flower's segments and reproductive structures (single pollinarium in Angraecum sect. Arachnangraecum, double pollinaria in Angraecum sect. Gomphocentrum and intermediate state in Angraecum magdalenae).

The genus Jumellea embraces species clearly separated from all other Angraecinae, taken into this analysis due to the peculiar position of the lip versus gynostemium. The lip of Jumellea is narrow and often clawed at the base and never enfolds the gynostemium, what results in the location ofthe lip below the gynostemium. In our opinion, this significant feature is a good background for retaining Jumellea as a separate genus. That is obvious that an outgroup to Jumellea, i.e. Angraecum section Perrierangraecum, and part of Angraecum represented by Angraecum sesquipedale and $A$. sororium deserve a generic status.

Clade A includes such distinct groups of angraecoids as Angraecum sect. Humblotiangraecum, sect. Arachnangraecum, sect. Gomphocentrum, Lemurochis, Oeoniella, Aeranthes and Bonniera, what means that

Table 1. Tree statistics for maximum parsimony analyses

\begin{tabular}{lrrr}
\hline & ITS & trnL-F & ITS/trnL-F \\
\hline Number of aligned position & 867 & 1905 & 2770 \\
Number of informative characters & 297 & 326 & 621 \\
Number of trees saved & +10000 & +10000 & 652 \\
Lenght of MP trees & 1517 & 1127 & 2736 \\
Consistency index CI & 0.404 & 0.684 & 0.502 \\
Retention index RI & 0.747 & 0.787 & 0.740 \\
\hline
\end{tabular}




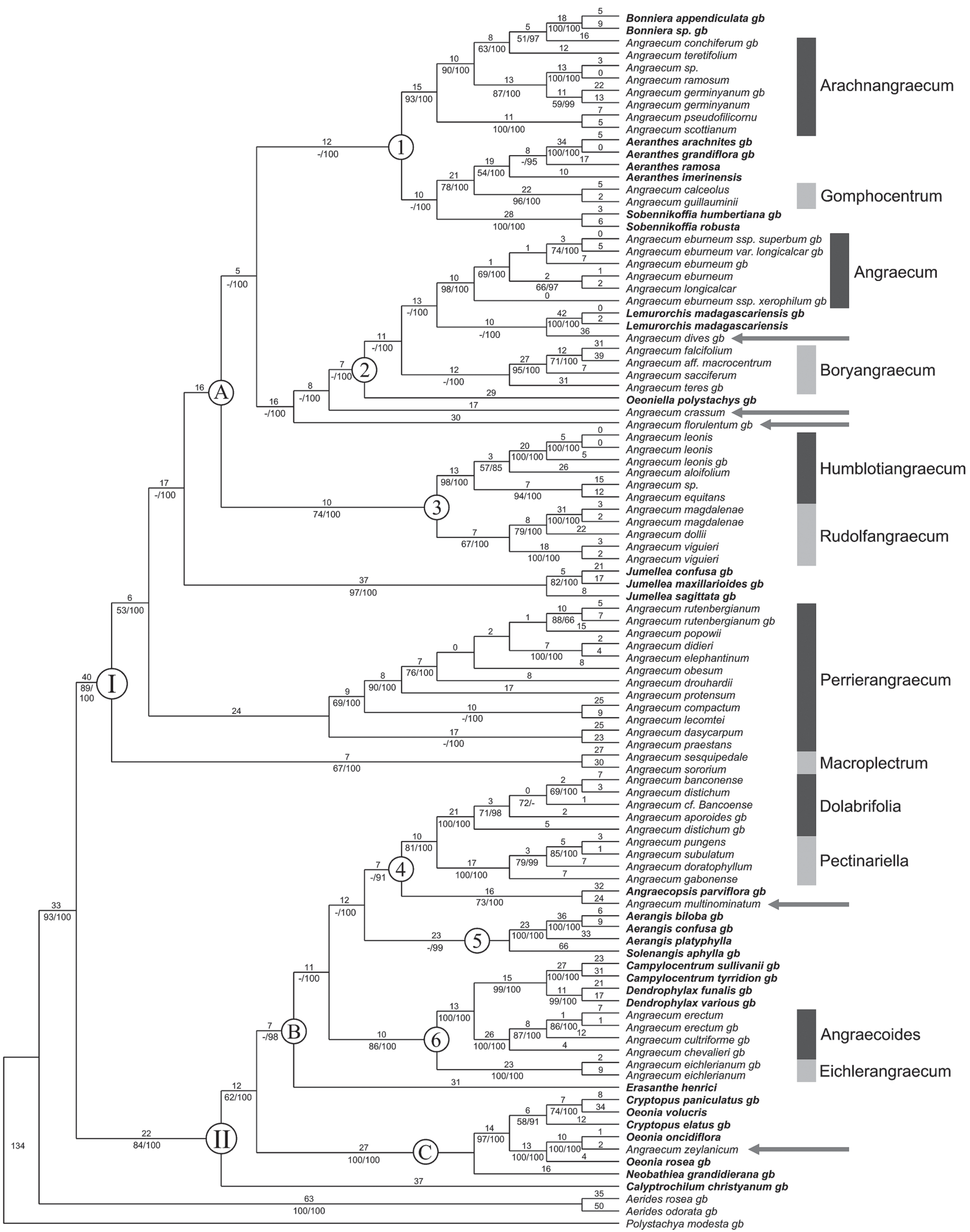

Fig. 1. One of the most parismonious trees from the combined analysis using maximum parsimony. The branch length is shown above and bootstrap support versus bayesian posterior probabilities below the branch (bp/pp); gb denotes sequences obtained from genbank resources. Single arrowheads on the right designate taxa with problematic placement and are discussed further in the text. 
they have no mutual evolutionary advanced feature. Moving down within clade A we can divide it into 3 subclades, neither of which is monomorphic enough to be defined by a set of features:

subclade 1 - Bonniera, Angraecum sect. Arachnangraecum, Aeranthes, Gomphocentrum, Sobennikoffia;

subclade 2 - Oeoniella, Lemurorchis, Angraecum s.str. \& A. sect. Boryangraecum;

subclade 3 - Angraecum sect. Humblotiangraecum $\&$ A. sect. Rudolfangraecum.

Clade II consists of two well supported clades of the continental African Angraecum species. One of these clades is sister to some genera included in Aerangidinae (Aerangis, Soelnangis) and the other is sister to the well supported (99 BP/100 PP) Neotropical Angraecinae (Campylocentrum, Dendrophylax). The monotypic Malagasy genus Erasanthe (formerly Aeranthes henrici sensu Cribb et al. 2007) remains sister to the groups described above. Another well supported clade (100 BP/100 PP) within clade II consists of some Malagasy angraecoid genera (Cryptopus, Oeonia, Neobathiea) and an interesting species of Angraecum zeylanicum known from Sri Lanka and Seychelles. Another interesting exception stands for Calyptrochilum christyanum. This species remains sister to the rest of the taxa in the clade II although its separated position is weakly supported by bootstrap (62 BP). Clade II, similarly like clade I, comprises so strongly diversified species that it is impossible to indicate any synapomorphy, even if we follow the procedure accepted above, i.e., to step down towards the species level. We were able to find out characteristic combination of features at the level corresponding roughly to the sections of Angraecum. Therefore, we propose the generic status for most of the sections proposed by Schlechter (1918) and Garay (1973), but with modified species contents.

Most of the sectional arrangements within the genus seems to be unnatural (Fig. 1), with few exceptions for the highly supported (100 BP/100 PP) African sections Dolabroflia (erected to the generic status by Szlachetko and Romowicz in 2007), Conchoglossum and Pectinaria. The latter section is not clearly monophyletic due to outstanding position of Angraecum dasycarpum in the clade I, as one of the three members of this section occurs outside continental Africa.

The position of Solenangis Schltr., Oeoniella Schltr. and particularly Aerangis Rchb.f. on the nrITS and trnL-F combined tree is enigmatic. Solenangis has been classified to Bolusiellinae and Oeoniella to Listrostachyinae by Szlachetko (1995) and it shares the similar type of rostellum, rostellum remnant and pollinarium with such genera as Nephrangis (Schltr.) Summerh. and Podangis Schltr. This type of gynostemium can be compared with Angraecopsis, Cribbia or some species of Campylocentrum. However, reproductive structures of Aerangis represent completely different level of organization - its rostellum and single tegula are greatly elongate, occasionally longer than column part, and viscidium is relatively small.

There is a group of Angraecum species that are nested in puzzling places on the tree presented in this article. Angraecum multinominatum Rendle is a member of the section Afrangraecum Summerh., typified by Angraecum reygaertii De Wild. and it does not appear to be drastically different from other member of the section. We can not explain its close relation with Angraecopsis parviflora (Thouars) Schltr. Analogical situation is observed in the case of Angraecum dives-Lemurorchis and Angraecum zeylanicum-Oeonia. Angraecum crassum Thouars was included in the nominal section of the genus Angraecum Garay (1973), but in our analysis it is sister to sublcade 2 including, amongst others, Oeoniella and Lemurorchis.

\subsection{The role of pollination in evolution of Angraecoid orchids}

Most of Angraecinae produce long-spurred white flowers emitting crepuscular scent, what is an adaptation to pollination by hawkmoths; these floral traits are consistent with the general syndrome of hawkmoth pollination (Grant 1985; Haber \& Frankie 1989). The angraecoids share similarities in floral morphology and one can deduce that pollinators play an important role in their evolution and speciation (Dressler 1981). In many species infundibular base of the spur provides enough space for insertion of the base of the pollinator's head into the flower. On contrary, there is a large group of angraecoids with narrow spur base, which can be penetrated by the narrow and long proboscis only. In many species a keel thickening is observed on the basal part of the lip and it can play a role of a guidepost, directing the proboscis to the spur exactly below pollinarium. In this case, the flower produces two separate pollinaria, each consisting of single viscidium, tegula and pollinium. These features, along with the various lengths of the spur, size of the flowers, their number and arrangement in inflorescence, as well as the large variability of vegetative parts responsible for adaptation to different environmental conditions, make possible the exploitation of a large spectrum of animals acting as pollinators.

An interesting pattern of spur morphology and nectar production was recently observed by Martins and Johnson (2007) in the Aerangis species examined in the eastern Africa. The authors revealed that some long-spurred species (Aerangis brachycarpa and $A$. confusa) have straight spurs, full of nectar, whereas in $A$. thomsonii and A. kotschyana, the nectar is located only in the basal third/quarter of the spur and, what is more interesting, the spurs of the latter species are spirally 
twisted (Martins \& Johnson 2007). Similar observations were made by Nilsson et al. (1985) in Angraecum arachnites in Madagascar.

Despite the fact that most of Angraecinae is pollinated by the representatives of Sphingidae, there are three Mascarenian species classified within the section Hadrangis Schltr. pollinated by birds and crickets, what was recently discovered (Micheneau et al. 2006, 2010, respectively). Angraecum striatum Thou., A. bracteosum Balf.f. \& S.Moore and A. cadetii Bosser, endemic to Mascarene Islands, are pollinated by small song-birds, Zosterops olivaceus and Z. borbonicus (Zosteropidae), the bird species endemic also to Rèunion (Micheneau et al. 2006). What is surprising, the orchids produce white flowers. Except for the colour, the flower morphology of A. striatum and A. bracteosum matches orchid-bird pollination syndrome (Micheneau et al. 2006). The bill of $Z$. borbonicus matches the flower entrance diameter perfectly and is suitable for both extracting nectar and performing pollination (Micheneau et al. 2006). Many examples show that flower colour is not necessarily correlated with pollination type (i.e. Momose et al. 1998; Johnson \& Steiner 2000) and flower colour within Angraecinae may be a conservative character. The third species, A. cadetii occurring on Rèunion and Mauritius, has a highly surprising pollinator, a raspy cricket (Gryllacrididae, the order Orthoptera) (Micheneau et al. 2010).

The section Hadrangis, entirely endemic to the Mascarenes, represents a case of an Angraecum intraarchipelago radiation (Micheneau et al. 2008a), the atypical flower morphology resulted from specific adaptation to the local pollinators, linked to the oceanic context of the Mascarene Archipelago (Micheneau et al. 2006).

There are also some long-spurred angraecoids (more than $9 \mathrm{~cm}$ ) on Rèunion, however all these species endemic to the island became totally independent of pollinators and are capable of autonomous selfpollination (Micheneau et al. 2006), what is probably caused by loosing an orchid-hawkmoth interaction (T. Pailler and C. Micheneau, unpublished). Therefore, an auto-pollination is linked to the absence of specific pollinator during the island colonization and species establishment, oceanic islands are known for the paucity of their insect fauna and often whole groups of insects are missing (Micheneau et al. 2008b).

These wide range of pollination syndrome within the angraecoid orchids on Rèunion is probably related to their recent dispersal to the Mascarene Islands, where specific long-tongue pollinators of ancestral orchid colonists were absent (Micheneau et al. 2008b [Jumellea]).

The floral morphology of Angraecinae is diverse suggesting some variation in pollination systems. Unfortunately, the observations of pollination mecha- nism are still scanty and give no authorization to formulate any hypothesis regarding significance of pollinator behavior and morphology in the speciation and evolution of this orchid group.

A key to the genera of Angraecinae:

1. Plants aphyllous .......................................................2

1. Plants leafy ..........................................................

2. Flowers more than $1 \mathrm{~cm}$ in diameter. Spur filiform or cylindrical, much longer than lip, at least three times as long as the lip Dendrophylax

2. Flowers smaller than $1 \mathrm{~cm}$ in diameter. Spur usually very short, up to twice as long as the lip ...................... 3 3 . Spur globose at the apex, with callus in the centre of the lip median lobe Harrisella 3. Spur blunt or saccate, never globose at the apex, lip without any callus Campylocentrum 4. Leaves equitant, basally imbricating .........................5 4. Leaves conduplicate .............................................. 6 5. Plants stemless, leaves oblong falcate, inflorescence few-flowered, flowers large, spur much longer than pedicellate ovary, orifice spacious

Humblotiangraecum

5. Plants with elongate stem, leaves dolabriform to elongate, inflorescence single-flowered, flowers small, spur almost equal in length to pedicellate ovary, orifice narrow

Dolabrifolia

6. Spur clavate to saccate, apically blunt, predominantly subequal in length to the pedicellate ovary ...... ...7 6. Spur filiform, occasionally somewhat swollen at the acute apex, orifice spacious, mostly much longer than pedicellate ovary .11

7. Leaf petiole twisted, hence, blades lying in one plane or so

Pectinariella

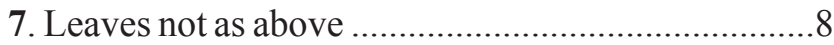

8. Flowers resupinate …..................................................

8. Flowers nonresupinate …………………………......10

9. Floral bracts oblong-ovate, much exceeding pedicellate ovary .....................................................Hadrangis 9. Floral bracts inconspicuous, shorter than pedicellate ovary Lepervenchea

10. Stem elongate, inflorescence shorter than leaves ...

Lemurangis

10. Stem abbreviated, inflorescence longer than leaves Lesliegraecum

11. Viscidium single ...................................................

11. Viscidia 2 .............................................................. 18

12. Rostellum slightly bent forwards, short and wide, obscurely 3-lobulate

Coenadenium

12. Rostellum dome-like, with deep and acute or shallow and gentle sinus in front ........................................13

13. Basal part of the lip below the gynostemium, not surrounding it Jumellea

13. Basal part of the lip cochleate, more or less surrounding the gynostemium 
14. Flowers resupinate, spur infundibuliform at the base .15

14. Flowers nonresupinate, spur orifice rather narrow .. .16 15. Viscidia double, but connate marginally to one another, forming a single structure. Lip large, ecallose ...

Rudolfangraecum

15. Viscidium single, lanceolate to ovate, oblong. Lip very large, transversely elliptic to obreniform, with prominent keel along midvein in the basal part

Eichlerangraecum

16. Tegula more or less plit apically, hence V-shaped .. Angraecoides

16. Tegula entire, more or less oblong .17

17. Inflorescence single-flowered, lip ecallose

Arachnangraecum

17. Inflorescence multiflowered, elongate, lip with basal keel. Angraecum

18. Flowers spurless or spur greatly reduced to shallow $\mathrm{sac}$

Bonniera

18. Spur with prominent spur . .19

19. Rostellum median lobe much longer than the column part Ambrella

19. Rostellum median lobe obscure, much shorter than the column part, digitate or reduced .20 20. Viscidia 2, tegula single Sobennikoffia

20. Viscidia 2, tegulae 2 .21

21. Column foot prominent, longer than the column part .22

21. Column foot usually absent or inconspicuous ....23

22. Lip margins entire Aeranthes

22. Lip margins fimbriate Erasanthe

23. Rostellum lateral lobes ribbon-like, prominent, curved down at the base and then abruptly upcurved ...Distylodon 23. Rostellum not as above .24

24. Gynostemium elongate, slender ..........................25

24. Gynostemium short, massive ..... .26

25 . Petals strongly asymmetric, partially connate with lateral sepals Angraecopsis 25. Petals more or less symmetric, free from lateral sepals Cribbia 26. Petals clawed, with apical more or less transversely elliptic plate. Tegulae densely and stiffly hairy ...Cryptopus 26. Petals not clawed, widest at the base. Tegulae glabrous .27 27. Spur entrance very large, its base broadly conical ... Neobathiea

27. Spur base cylindrical .28

28. Flowers nonresupinate 29

28. Flowers resupinate .30

29. Lip prominently 3 -lobed Lemurella

29. Lip unlobed or obscurely 3-lobed .31

30. Lip thin-textured, ovate-lanceolate, spur longer than pedicellate ovary, filiform, straight, somewhat swollen at the apex, with narrow entrance

Hermansia
30. Lip fleshy, transversely elliptic, spur relatively short, hardly exceeding pedicellate ovary, straight, swollen and blunt at the apex

Boryangraecum 31. Lip 3-lobed, the middle lobe often bilobulate

Oeonia

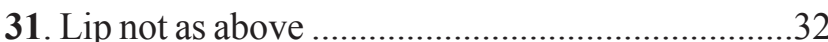

32. Inflorescence usually densely and many-flowered

Campylocentrum

32. Inflorescence usually 1 - to few-flowered ...........33

33. Stem with elongate internodes, inflorescence always 1-flowered

Pseudojumellea

33. Stem with abbreviated internodes, inflorescence usually few-flowered

.34

34. Flowers small, inconspicuous, resupinate, greenish to yellowish, thin in texture, rather diaphanous

Gomphocentrum

34. Flowers large, showy, ivory-coloured, not diaphanous

.35

35. Spur base very narrow, filiform

35. Spur base narrowly conical

Perrierangraecum Macroplectrum

\subsection{Taxonomic treatment}

1. Angraecoides (Cordem.) Szlach., Mytnik \& Grochocka, stat. et gen. nov.

B a s i o n y m : Mystacidium Lindl. sect. Angraecoides Cordem., Rev. Gen. Bot. 11: 421. 1900; G e n e r i type: Angraecum pingue Frapp. [三 Angraecoides pingue (Frapp.) Szlach., Mytnik \& Grochocka]. = Angraecum Bory sect. Conchoglossum Schltr., Beih. Bot. Centralbl.36(2): 157.1918; Ty p e s pecies (Garay 1973: 499): Angraecum viride Kraenzl.

Plants medium-sized. Stem elongate, internodes prominent. Leaves in two rows, ligulate to lanceolate-ovate, unequally bilobed at the apex, sheaths compressed, loosely enclothing stem. Inflorescence usually 1-flowered. Peduncle usually shorter than internodes, enclothed basally by 1-2 adpressed bracts. Flowers small to medium-sized, greenish, yellowish, pinkishbrown to white, nonresupinate. Floral bracts inconspicuous. Pedicellate ovary terete. Sepals and petals subsimilar, narrowly lanceolate or linear-lanceolate, acute to acuminate. Lip longer than wide, often petaloid, concave in the center, with more or less oblong or linear callus in the middle, acuminate. Spur more or less as long as the lip, sometimes slightly exceeding it or shorter, slender, narrowly cylindrical, somewhat swollen at the apex, orifice narrow. Tegula more or less split at the apex, hence V-formed, viscidium single.

The genus, as proposed here, combines two Garay's (1973) sections of Angraecum, i.e. Angraecoides (Cordem.) Garay and Conchoglossum Schltr. In our opinion, the distinguishing character of these sections (peduncle prominent vs usually short) is neither constant nor important enough to substantiate 
such proposal. Angraecoides appears to be related to Eichlerangraecum from which it is easily separable by the flower and tegula morphology. The species of Angraecoides produce smaller flowers, which are inconspicuous, with narrow spur orifice and petaloid lip, what is probably an adaptation to pollination by small, long-proboscis insects. Large flowers with a broad and spacious, infundibular spur entrance, seen in Eichlerangraecum, can easily accomodate head and thorax of larger insects. Tegula of the Angraecoides species is V-shaped, whereas in Eichlerangraecum is single, undivided.

The genus includes 25 species.

Angraecoides angustipetala (Rendle) Szlach., Mytnik \& Grochocka, comb. nov.

B a s i o ny m: Angraecum angustipetalum Rendle, Cat. Pl. Oban: 106. 1913.

Angraecoides brevicornu (Summerh.) Szlach., Mytnik \& Grochocka, comb. nov.

B a s i o n y m: Angraecum brevicornu Summerh., Kew Bull. 16: 311. 1962.

Angraecoides chermezonii (H. Perrier) Szlach., Mytnik \& Grochocka, comb. nov.

$\mathrm{B}$ a s i o ny m: Angraecum chermezonii H. Perrier, Notul. Syst. (Paris) 7: 107. 1938.

Angraecoides cilaosiana (Cordem.) Szlach., Mytnik \& Grochocka, comb. nov.

B a si ony m: Mystacidium cilaosianum Cordem., Rev. Gén. Bot. 11: 424. 1899. 三 Angraecum cilaosianum (Cordem.) Schltr., Beih. Bot. Centralbl. 33(2): 432. 1915

Angraecoides clavigera (Ridl.) Szlach., Mytnik \& Grochocka, comb. nov.

B a s i o n y m: Angraecum clavigerum Ridl., J. Linn. Soc., Bot. 21: 485. 1885.

Angraecoides cultriforme (Summerh.) Szlach., Mytnik \& Grochocka, comb. nov.

B a s i o n y m: Angraecum cultriforme Summerh., Kew Bull. 13: 272. 1958.

Angraecoides curvicaule (Schltr.) Szlach., Mytnik \& Grochocka, comb. nov.

B a s i o n y m: Angraecum curvicaule Schltr., Repert. Spec. Nov. Regni Veg. Beih. 33: 346. 1925.

Angraecoides curvipes (Schltr.) Szlach., Mytnik \& Grochocka, comb. nov.

B a s i o n y m: Angraecum curvipes Schltr., Bot. Jahrb. Syst. 38: 21. 1905.

Angraecoides egertonii (Rendle) Szlach., Mytnik \& Grochocka, comb. nov.

B a s i o n y m: Angraecum egertonii Rendle, Cat. Pl. Oban: 107. 1913.

Angraecoides elliotii (Rolfe) Szlach., Mytnik \& Grochocka, comb. nov.

B a s i o n y m: Angraecum elliotii Rolfe, J. Linn. Soc., Bot. 29: 54. 1891.
Angraecoides erecta (Summerh.) Szlach., Mytnik \& Grochocka, comb. nov.

B a s i ony m: Angraecum erectum Summerh., Kew Bull. 11: 232. 1956.

Angraecoides keniae (Kraenzl.) Szlach., Mytnik \& Grochocka, comb. nov.

B a s i o n y m : Angraecum keniae Kraenzl., Bot. Jahrb. Syst. 17: 59. 1893.

Angraecoides modica (Summerh.) Szlach., Mytnik \& Grochocka, comb. nov.

B a s i o n y m: Angraecum modicum Summerh., Kew Bull. 13: 84. 1958.

Angraecoides nasuta (Schltr.) Szlach., Mytnik \& Grochocka, comb. nov.

B a si o ny m: Angraecum nasutum Schltr., Repert. Spec. Nov. Regni Veg. Beih. 33: 315. 1925.

Angraecoides obversifolia (Frapp. ex Cordem.) Szlach., Mytnik \& Grochocka, comb. nov.

B a si on y m: Angraecum obversifolium Frapp. ex Cordem., Fl. Réunion: 212. 1895.

Angraecoides panicifolia (H. Perrier) Szlach., Mytnik \& Grochocka, comb. nov.

B a si onym: Angraecum panicifolium H.Perrier, Notul. Syst. (Paris) 7: 105. 1938.

Angraecoides pingue (Frapp. ex Cordem.) Szlach., Mytnik \& Grochocka, comb. nov.

B a s i o n y m: Angraecum pingue Frapp. ex Cordem., Fl. Réunion: 214. 1895.

Angraecoides rhizomaniaca (Schltr.) Szlach., Mytnik \& Grochocka, comb. nov.

B a s i onym: Angraecum rhizomaniacum Schltr., Repert. Spec. Nov. Regni Veg. Beih. 33: 315. 1925.

Angraecoides rostrata (Ridl.) Szlach., Mytnik \& Grochocka, comb. nov.

B a s i o n y m: Angraecum rostratum Ridl., J. Linn. Soc., Bot. 21: 485. 1885.

Angraecoides scalariforme (H. Perrier) Szlach., Mytnik \& Grochocka, comb. nov.

B a si onym: Angraecum scalariforme H.Perrier, Mém. Inst. Sci. Madagascar, Sér. B, Biol. Vég. 6: 265. 1955.

Angraecoides sedifolia (Schltr.) Szlach., Mytnik \& Grochocka, comb. nov.

B a s i o ny m: Angraecum sedifolium Schltr., Repert. Spec. Nov. Regni Veg. Beih. 33: 316. 1925.

Angraecoides stolzii (Schltr.) Szlach., Mytnik \& Grochocka, comb. nov.

B a s i o ny m: Angraecum stolzii Schltr., Bot. Jahrb. Syst. 53: 603. 1915.

Angraecoides triangulifolia (Senegas) Szlach., Mytnik \& Grochocka, comb. nov.

B a si o n y m: Angraecum triangulifolium Senghas, Adansonia, n.s., 4: 310. 1964.

Angraecoides viride (Kraenzl.) Szlach., Mytnik \& Grochocka, comb. nov. 
B a s i o n y m: Angraecum viride Kraenzl., Bot. Jahrb. Syst. 51: 395. 1914.

Angraecoides zaratananae (Schltr.) Szlach., Mytnik \& Grochocka, comb. nov.

B a s i o n y m: Angraecum zaratananae Schltr., Repert. Spec. Nov. Regni Veg. Beih. 33: 317. 1925.

\section{Angraecum Bory}

Voy. 1: 359, t. 19. 1804;

Ge n e ri ty pe: Angraecum eburneum Bory.

Plants usually very large, often caespitose. Stem elongate, stout, leafy. Leaves long, linear, thick, leathery, stiff, unequally bilobed at the apex. Inflorescence elongate, multiflowered. Flowers large, fleshy, conspicuous, nonresupinate. Floral bracts prominent, amplexicaul. Pedicellate ovary ribbed. Sepals and petals subsimilar, lanceolate, acute. Lip more or less transversely elliptic, concave, cochleate, with basal keel, apically obscurely 3-lobed, long acuminate. Spur narrowly cylindrical to filiform, acute, base narrow, pendent. Viscidium single, elliptic-ovate, tegula elongate, oblanceolate, longer than tegula.

The genus as proposed here is limited to the species of Angraecum eburnem-complex. In their habit they are similar to both Lemurorchis and Hadrangis, but have completely different, nonresupinate flowers.

\section{Arachnangraecum (Schltr.) Szlach., Mytnik \& Gro-} chocka, stat. et. gen. nov.

B a s i o n y m: Angraecum Bory sect. Arachnangraecum Schltr., Repert. Sp. Nov. Regni Veg., Beih. 33: 309. 1925; L e c to ty pe (Garay 1973: 501): Angraecum ramosum Thouars [三 Arachnangraecum ramosum (Thouars) Szlach., Mytnik \& Grochocka].

Stem elongate, erect to pendent. Leaves numerous, ligulate to linear, unequally bilobed. Inflorescence 1-flowered. Flowers showy, relatively large, nonresupinate. Peduncle slender, longer than internodes, with 1-2 sheaths at the base. Floral bracts inconspicuous. Sepals and petals subsimilar, usually long-acuminate to caudate, acute. Lip large, suborbicluar, concave at the base, usually long-acuminate at the apex, ecallose. Spur long, filiform, acute, somewhat wider at entrance. Viscidium single, elliptic, small. Tegula oblong-oblanceolate to ligulate, longer than viscidium, single.

The genus includes the species producing flowers which resemble those of Angraecum, especially in the position and morphology of the lip. Although, the lip of Arachnangraecum is devoid of any keel and the spur orifice is rather wide, enabling pollinators to insert the whole head inside the flower, and not only the proboscis. Very peculiar aspect of the flowers are widely spread, caudate tepals, giving the flower a spider appearence.

The genus includes 13 species.
Arachnangraecum ampullaceum (Bosser) Szlach., Mytnik \& Grochocka, comb. nov.

B a s i o n y m: Angraecum ampullaceum Bosser, Adansonia, n.s., 10: 109. 1970.

Arachnangraecum conchiferum (Lindl.) Szlach., Mytnik \& Grochocka, comb. nov.

B a s i o n y m: Angraecum conchiferum Lindl., Companion Bot. Mag. 2: 205. 1836.

Arachnangraecum danguyanum (H. Perrier)

Szlach., Mytnik \& Grochocka, comb. nov.

B a si on y m: Angraecum danguyanum H. Perrier, Notul. Syst. (Paris) 7: 107. 1938.

Arachnangraecum expansum (Thouars) Szlach., Mytnik \& Grochocka, comb. nov.

B a si o ny m: Angraecum expansum Thouars, Hist. Orchid.: 57. 1822.

Arachnangraecum germinyanum (Hook. f.) Szlach., Mytnik \& Grochocka, comb. nov.

$\mathrm{B}$ a s i o n y m: Angraecum germinyanum Hook. f. Bot. Mag. 115: t. 7061. 1889.

Arachnangraecum humbertii (H. Perrier) Szlach., Mytnik \& Grochocka, comb. nov.

B a s i o n y m: Angraecum humbertii H. Perrier., Notul. Syst. (Paris) 8: 46. 1939.

Arachnangraecum linearifolium (Garay) Szlach., Mytnik \& Grochocka, comb. nov.

B a s i o n y m: Angraecum linearifolium Garay, Bot. Mus. Leafl. 23: 160. 1972.

= Angraecum palmiforme H. Perrier, Mém. Inst. Sci. Madagascar, Sér. B, Biol. Vég. 6: 268. 1955, nom. illeg.

Arachnangraecum mirabile (Schltr.) Szlach., Mytnik \& Grochocka, comb. nov.

B a si on ym: Angraecum mirabile Schltr., Repert. Spec. Nov. Regni Veg. 15: 338. 1918.

Arachnangraecum pseudofilicornu (H. Perrier) Szlach., Mytnik \& Grochocka, comb. nov.

$\mathrm{B}$ a s i o n y m: Angraecum pseudofilicornu H. Perrier, Notul. Syst. (Paris) 7: 108. 1937.

Arachnangraecum ramosum (Thouars) Szlach., Mytnik \& Grochocka, comb. nov.

B a si on ym: Angraecum ramosum Thouars, Hist. Orchid.: 59. 1822.

Arachnangraecum scottianum (Rchb. f.) Szlach., Mytnik \& Grochocka, comb. nov.

B a s i o n y m: Angraecum scottianum, Rchb. f., Gard. Chron., n.s., 10(2): 556. 1878.

Arachnangraecum sterrophyllum (Schltr.) Szlach., Mytnik \& Grochocka, comb. nov.

B a s i on y m: Angraecum sterrophyllum Schltr., Beih. Bot. Centralbl. 34(2): 338. 1916.

Arachnangraecum teretifolium (Ridl.) Szlach., Mytnik \& Grochocka, comb. nov.

B a s i o n y m: Angraecum teretifolium Ridl., J. Linn. Soc., Bot. 21: 484. 1885. 
4. Boryangraceum (Schltr.) Szlach., Mytnik \& Grochocka, stat. et gen. nov.

B a s i o n y m: Angraecum Bory sect. Boryangraecum Schltr., Repert. Sp. Nov. Regni Veg., Beih. 33: 308. 1925; Le ctoty pe (Garay 1973: 502): Angraecum pumilio Schltr. [三 Boryangraceum pumilio (Schltr.) Szlach., Mytnik \& Grochocka].

Plants small. Stem hardly developed, usually much abbreviated. Leaves linear to oblong-lanceolate, unequally bilobed at the apex. Inflorescence elongate, several-flowered. Floral bracts prominent, amplexicaul. Pedicellate ovary terete. Flowers small, nonresupinate, diaphanous, yellowish, ochraceous, whittish, greenish. Sepals and petals dissimilar, acute. Lip rather fleshy, obscurely 3-lobed, transversely elliptic, cochleate, canaliculate, lateral lobes upcurved, apex acute to acuminate. Spur relatively short, hardly exceeding pedicellate ovary, straight, swollen and blunt at the apex. Tegulae and viscidia double.

Boryangraceum appears to be similar to Lemurangis, but both genera are well separated by pollinarium structure. There are two pollinaria in the former and single in the latter genus. Additionally, the stem of Lemurangis is elongate with short leaves, while the stem of Boryangraecum is short, abbreviated with long leaves. Boryangraceum shares similar type of pollinaria with Gomphocentrum, but our molecular analyses suggest that it can be a result of homoplasy. It is coherent with flower morphology of both genera. The flowers of Gomphocentrum are resupinate with filiform spur with narrow entrance.

Boryangraecum includes 13 species.

Boryangraecum aviceps (Schltr.) Szlach., Mytnik \& Grochocka, comb. nov.

B a si onym: Angraecum aviceps Schltr., Repert. Spec. Nov. Regni Veg. Beih. 33: 335. 1925.

Boryangraecum flavidum (Bosser) Szlach., Mytnik \& Grochocka, comb. nov.

B a s i o n y m: Angraecum flavidum Bosser, Adansonia, n.s., 10: 100. 1970.

Boryangraecum myrianthum (Schltr.) Szlach., Mytnik \& Grochocka, comb. nov.

B a s i o n y m: Angraecum myrianthum Schltr., Ann. Inst. Bot.-Géol. Colon. Marseille, III, 1: 197. 1913.

Boryangraecum ochraceum (Schltr.) Szlach., Mytnik \& Grochocka, comb. nov.

B a s i o n y m: Mystacidium ochraceum Ridl., J. Linn. Soc., Bot. 21: 488. 1885.

Boryangraecum pinifolium (Bosser) Szlach., Mytnik \& Grochocka, comb. nov.

B a s i o n y m: Angraecum pinifolium Bosser, Adansonia, n. s., 10: 99. 1970.

Boryangraecum pumilio (Schltr.) Szlach., Mytnik \& Grochocka, comb. nov.

B a s i o n y m: Angraecum pumilio Schltr., Beih. Bot. Centralbl. 34(2): 337. 1916.
Boryangraecum ramulicolum (H .Perrier) Szlach., Mytnik \& Grochocka, comb. nov.

B a s i on y m: Angraecum ramulicolum H. Perrier, Notul. Syst. (Paris) 7: 123. 1938.

Boryangraecum sacciferum (Lindl.) Szlach., Mytnik \& Grochocka, comb. nov.

B a s i o n y m: Angraecum sacciferum Lindl., Companion Bot. Mag. 2: 205. 1836.

Boryangraecum sinuatiflorum (H. Perrier) Szlach., Mytnik \& Grochocka, comb. nov.

B a s i o n y m: Angraecum sinuatiflorum H. Perrier, Notul. Syst. (Paris) 14: 163. 1951.

Boryangraecum tamarindicolum (Schltr.) Szlach., Mytnik \& Grochocka, comb. nov.

B a si o ny m: Angraecum tamarindicolum Schltr., Repert. Spec. Nov. Regni Veg. Beih. 33: 340. 1925.

Boryangraecum teres (Summerh.) Szlach., Mytnik \& Grochocka, comb. nov.

B a s i o n y m: Angraecum teres Summerh., Kew Bull. 13: 265.1958.

Boryangraecum vesiculiferum (Schltr.) Szlach., Mytnik \& Grochocka, comb. nov.

B a si onym: Angraecum vesiculiferum Schltr., Repert. Spec. Nov. Regni Veg. Beih. 33: 341. 1925.

Boryangraecum xylopus (Rchb.f.) Szlach., Mytnik \& Grochocka, comb. nov.

B a s i o n y m: Angraecum xylopus Rchb.f., Flora 68: 538. 1885.

5. Dolabrifolia (Pfitzer) Szlach. \& Romowicz Richardiana 7: 54. 2007. $\equiv$ Mystacidium Lindl. sect. Dolabrifolia Pfitz. in Engl. \& Prantl, Natürl. Pflanzenfam. 2(6): 216. 1889; G e n e r i t y p e : Angraecum distichum Lindl. [ [三 Dolabrifolia disticha (Lind1.) Szlach. \& Romowicz] $\equiv$ Angraecum Bory sect. Dolabrifolia (Pfitz.) Garay, Kew Bull. 28(3): 499. 1973.

$=$ Aeranthus Lindl. sect. Dolabrifolia Rchb.f., Walp., Ann. Bot. Syst. 6: 901. 1864, nom. nud.

$=$ Epidorchis Thouars sect. Dolabraria Kuntze in Post \& Kuntze, Lex. Gen. Phan.: 200. 1903, nom. illegit.

Small, caespitose plant with elongate stem. Leaves distichous, equitant, basally imbricating, somewhat fleshy, thick. Inflorescence 1-flowered, almost sessile, peduncle very short. Flowers tiny, nonresupinate, pure white. Floral bracts amplexicaul. Pedicellate ovary terete. Sepals and petals dissimilar, petals smaller and narrower. Lip transversely elliptic, more or less 3-lobed at the apex, acuminate apically, cochleate and canaliculate, ecallose. Spur cylindrical, more or less as long as the pedicellate ovary, orifice rather narrow.

The genus is easily distinguished from all other Angraecinae by its peculiar habit, equitant, short leaves and short-pedunculed inflorescence. It includes $4-5$ species depending on the authors. 
Dolabrifolia aporoides (Summerh.) Szlach. \& Romowicz

Richardiana 7: 54. 2007. 三Angraecum aporoides Summerh., Kew Bull. 17: 560. 1964.

Dolabrifolia bancoensis (Burg) Szlach \& Romowicz Richardiana 7: 54. 2007. Angraecum bancoensis Burg, Misc. Pap. Landbouwhogeschool, Wageningen 19: 26.1980.

Dolabrifolia disticha (Lindl.) Szlach. \& Romowicz Richardiana 7: 54. 2007. 三Angraecum distichum Lindl., Edwards's Bot. Reg. 21: t. 1781. 1836.

Dolabrifolia podochiloides (Schltr.) Szlach. \& Romowicz

Richardiana 7: 54. 2007. $\equiv$ Angraecum podochiloides Schltr., Bot. Jahrb. Syst. 38: 162. 1906.

Dolabrifolia poppendickiana (Szlach. \& Olszewski) Szlach. \& Romowicz

Richardiana 7: 54. 2007. $\equiv$ Angraecum poppendickianum Szlach. \& Olszewski, Fl. Cameroun 36: 884. 2001.

6. Eichlerangraecum Szlach., Mytnik \& Grochocka, gen. nov.

Stem long, climbing, internodes elongate, leaves alternate. Inflorescence usually 1-4-flowered. Flowers resupinate, large, showy. Lip very large, transversely elliptic to obreniform, cochleate in the center, with prominent keel along the midvein in the basal part. Spur very prominent, infundibular in the basal part. Tegula single, oblong-elliptic, viscidium single, lanceolate to ovate, oblong.

G e n e r i t y p e : Angraecum eichlerianum Kraenzl. [ [ Eichlerangraecum eichlerianum (Kraenzl.) Szlach., Mytnik \& Grochocka].

E t y m o log y: A combination of the specific epithet of the generitype and the name Angraecum.

Plants rather large. Stem long, climbing, internodes elongate, leaves alternate. Leaves oblong to elliptic, unequally bilobed at the apex. Inflorescence usually 1-4-flowered. Flowers resupinate, large, showy. Floral bracts inconspicuous. Pedicellate ovary slender, terete. Sepals and petals subsimilar, narrowly lanceolate to linear-lanceolate, acute, spread. Lip very large, transversely elliptic to obreniform, cochleate in the centre becoming conical towards the base, more or less apiculate at the apex, more or less 3-lobed at the apex, with prominent keel along the midvein in the basal part. Spur very prominent, infundibular in the basal part, slender, cylindrical above, attenuate towards the apex. Tegula single, oblong-elliptic, viscidium single, lanceolate to ovate, oblong.

The genus includes four species known from continental Africa, three of them occur in western Africa, the fourth, E. spectabile, has been noted in Tanzania. They were classified within the section Arachnangraecum
Schltr. by Schlechter (1918) and Garay (1973), which was typified by Garay (1973) by Angraecum ramosum Thouars, and intermixed along with such species as Angraecum conchiferum Lindl., A. teretifolium Ridl. and $A$. viguieri Schltr. All the taxa are characterised by similar habit, but differ in the flower details, such as the lip form. The results of our molecular analyses clearly indicate that the section broadly defined is polyphyletic.

Eichlerangraecum birrimense (Rolfe) Szlach., Mytnik \& Grochocka, comb. nov.

B a si onym: Angraecum birrimense Rolfe, Bull. Misc. Inform. Kew 1914: 214. 1914.

Eichlerangraecum eichlerianum (Kraenzl.) Szlach., Mytnik \& Grochocka, comb. nov.

B a si onym: Angraecum eichlerianum Kraenzl., Berliner Allg. Gartenzeitung 1: 434. 1882.

Eichlerangraecum eichlerianum (Kraenzl.) Szlach., Mytnik \& Grochocka var. curvicalcaratum (Szlach. \& Olszewski) Szlach., Mytnik \& Grochocka, comb. nov., B a s i o n y m: Angraecum eichlerianum Kraenzl. var curvicalcaratum Szlach. \& Olszewski, Fl. Cameroun, Orchid. 36: 898. 2001.

Eichlerangraecum infundibulare (Lindl.) Szlach., Mytnik \& Grochocka, comb. nov.

B a si o nym: Angraecum infundibulare Lindl., J. Proc. Linn. Soc., Bot. 6: 136. 1862.

Eichlerangraecum spectabile (Summerh.) Szlach., Mytnik \& Grochocka, comb. nov.

B a s i o n y m: Angraecum spectabile Summerh., Kew Bull. 13: 274. 1958.

7. Gomphocentrum (Benth.) Szlach., Mytnik \& Grochocka, stat. et gen. nov.

B a si onym: Mystacidium Lindl. sect. Gomphocentrum Benth., J. Linn. Soc. Bot. 18: 337. 1881; Generitype: Angraecum caulescens Thouars $[\equiv$ Gomphocentrum caulescens (Thouars) Szlach., Mytnik \& Grochocka]. 三 Angraecum sect. Gomphocentrum (Benth.) Garay, Kew Bull. 28(3): 501. 1973.

Plants medium-sized. Stem elongate or more often abbreviated, erect. Leaves lanceolate to oblong-lanceolate, attenuate and unequally bilobed at the apex, thin . Inflorescence elongate, peduncle thin, wiry, somewhat fractiflex, usually laxly several- to many-flowered. Flowers small, inconspicuous, resupinate, greenish to yellowish, thin in texture, rather diaphanous. Floral bracts inconspicuous. Pedicellate ovary ribbed. Sepals and petals subsimilar, acute. Lip ovate, long-acuminate, strongly cochleate, ecallose. Spur cylindrical, with narrow entrance, apex swollen or not. Viscidia 2, small, elliptic, tegulae 2, oblong-oblanceolate, thin.

Molecular analyses indicate close relationships between this genus and Aeranthes Lindl. They share similar habit, leaf form and texture, but are essentially different in the flower morphology. 
The genus, as proposed here, includes 18 species.

Gomphocentrum acutipetalum (Schltr.) Szlach., Mytnik \& Grochocka, comb. nov.

B a s i o n y m : Angraecum acutipetalum Schltr., Beih. Bot. Centralbl. 34(2): 337. 1916.

Gomphocentrum andringitranum (Schltr.) Szlach., Mytnik \& Grochocka, comb. nov.

B a s i o ny m: Angraecum andringitranum Schltr., Repert. Spec. Nov. Regni Veg. Beih. 33: 344. 1925.

Gomphocentrum calceolus (Thouars) Szlach., Mytnik \& Grochocka, comb. nov.

B a s i on y m: Angraecum calceolus Thouars, Hist. Orchid.: t. 77. 1822.

Gomphocentrum caulescens (Thouars) Szlach., Mytnik \& Grochocka, comb. nov.

B a si on ym: Angraecum caulescens Thouars, Hist. Orchid.: t. 75. 1822.

Gomphocentrum cordemoyi (Schltr.) Szlach., Mytnik \& Grochocka, comb. nov.

B a s i o ny m: Angraecum cordemoyi Schltr., Beih. Bot. Centralbl. 33(2): 432.1915.

Gomphocentrum cornucopiae (H. Perrier) Szlach., Mytnik \& Grochocka, comb. nov.

B a s i o n y m: Angraecum cornucopiae H. Perrier, Mém. Inst. Sci. Madagascar, Sér. B, Biol. Vég. 6: 265. 1955.

Gomphocentrum crassifolium (Schltr.) Szlach., Mytnik \& Grochocka, comb. nov.

B a s i o ny m: Mystacidium crassifolium Cordem., Rev. Gén. Bot. 11: 422. 1899. 三 Angraecum crassifolium (Cordem.) Schltr., Beih. Bot. Centralbl. 33(2): 433.1915.

Gomphocentrum dauphinense (Schltr.) Szlach., Mytnik \& Grochocka, comb. nov.

B a si onym: Mystacidium dauphinense Rolfe ex Scott-Elliot, J. Linn. Soc., Bot. 29: 55. 1891. =Angraecum dauphinense (Rolfe) Schltr., Beih. Bot. Centralbl. 33(2): 433. 1915.

Gomphocentrum guillauminii (H. Perrier) Szlach., Mytnik \& Grochocka, comb. nov.

B a s i onym: Angraecum guillauminii H. Perrier, Bull. Mus. Natl. Hist. Nat., II, 22: 114. 1950.

Gomphocentrum inapertum (Thouars) Szlach., Mytnik \& Grochocka, comb. nov.

B a s i on ym: Angraecum inapertum Thouars, Hist. Orchid.: 50. 1822.

Gomphocentrum laggiarae (Schltr.) Szlach., Mytnik \& Grochocka, comb. nov.

B a s i on ym: Angraecum laggiarae Schltr., Repert. Spec. Nov. Regni Veg. 15: 337. 1918.

Gomphocentrum multiflorum (Thouars) Szlach., Mytnik \& Grochocka, comb. nov.

B a s i o n y m: Angraecum multiflorum Thouars, Hist. Orchid.: 74. 1822.

Gomphocentrum rhizanthium (H. Perrier) Szlach., Mytnik \& Grochocka, comb. nov.
B a s i o nym: Angraecum rhizanthium H. Perrier, Notul. Syst. (Paris) 14: 163. 1951.

Gomphocentrum sacculatum (Schltr.) Szlach., Mytnik \& Grochocka, comb. nov.

B a s i o n y m: Angraecum sacculatum Schltr., Repert. Spec. Nov. Regni Veg. Beih. 33: 347. 1925.

Gomphocentrum tenuipes (Summerh.) Szlach., Mytnik \& Grochocka, comb. nov.

B a s i o ny m: Angraecum tenuipes Summerh., Kew Bull. 6: 473. 1951 (publ. 1952).

Gomphocentrum undulatum (Schltr.) Szlach., Mytnik \& Grochocka, comb. nov.

B a s i o n y m: Mystacidium undulatum Cordem., Rev. Gén. Bot. 11: 425. 1899. 三Angraecum undulatum (Cordem.) Schltr., Beih. Bot. Centralbl. 33(2): 348. 1915.

Gomphocentrum verecundum (Schltr.) Szlach., Mytnik \& Grochocka, comb. nov.

Basionym: Angraecum verecundum Schltr., Repert. Spec. Nov. Regni Veg. Beih. 33: 348. 1925.

Gomphocentrum vesiculatum (Schltr.) Szlach., Mytnik \& Grochocka, comb. nov.

B a s i on y m: Angraecum vesiculatum Schltr., Repert. Spec. Nov. Regni Veg. Beih. 33: 348. 1925.

8. Hadrangis (Schltr.) Szlach., Mytnik \& Grochocka, stat. et gen. nov.

B a s i o nym: Angraecum Bory sect. Hadrangis Schltr., Beih. Bot. Centralbl. 36(2): 158. 1918; Ge$\mathrm{n}$ e r i ty p e: Angraecum striatum Thouars [ $[$ Hadrangis striata (Thouars) Szlach., Mytnik \& Grochocka]. = Angraecum sect. Thouarsiangraecum Schltr., Repert. Sp. Nov. Regni Veg, Beih. 33: 310. 1925; nom. illegit. $\mathrm{G}$ e $\mathrm{n}$ e r ity pe: Angraecum striatum Thouars.

Stem short, stout, erect, leafy. Leaves ligulate to oblong, stiff, unequally bilobed at the apex, coriaceous or leathery. Inflorescence several-flowered. Flowers fleshy, resupinate, rather small to medium-sized. Floral bracts conspicuous, oblong-ovate. Ovary shortly pedicellate. Sepals and petals subsimilar, ovate-lanceolate, acute. Lip ovate-lanceolate, unlobed, long-acuminate, concave, ecallose. Spur short, conical to saccate, obtuse at the apex, orifice wide.

We had no access to any materials proper to molecular analyses representing this group. The species of the genus appear to be similar to those of Lemurorchis. They share similar habit, long, multiflowered inflorescence and general flower morphology, but differ clearly one from another by the lip and spur morphology. Lip of Lemurochis is deeply 3-lobed, with both lateral lobes transversely elliptic, upcurved forming a kind of tube around gynostemium and spur entrance. It produces long, cylindrical spur. Lip of Hadrangis is concave and spur is short, conical to saccate. These differencies are probably result of adaptation to different pollination systems or different groups of pollinators. 
Hadrangis bracteosa (Balf. f. \& S. Moore) Szlach., Mytnik \& Grochocka, comb. nov.

B a si on ym: Angraecum bracteosum Balf. f. \& S. Moore, J. Bot. 14: 293. 1876.

Hadrangis cadetii (Bosser) Szlach., Mytnik \& Grochocka, comb. nov.

B a s i o n y m: Angraecum cadetii Bosser, Bull. Mus. Nation. Hist. Nat., B, Adansonia, Ser. 4, 9(3): 252. 1987.

Hadrangis striata (Thouars) Szlach., Mytnik \& Grochocka, comb. nov.

B a s i ony m: Angraecum striatum Thouars, Hist. Orchid.: 72. 1822.

9. Hermansia Szlach., Mytnik \& Grochocka, nom. et stat. nov.

Replaced sy nonym: Angraecum Bory sect. Acaulia Garay, Kew Bull. 28(3): 498. 1973; Generitype: Angraecum rhynchoglossum Schltr. [三 Hermansia rhynchoglossa (Schltr.) Szlach., Mytnik \& Grochocka].

E t y m o log y: Dedicated to Johan Hermans, specialist of angrecoid orchids.

Plants small. Stem abbreviated, very short. Leaves several, linear to oblong-ligulate, unequally bilobed at the apex. Inflorescence elongate, usually longer than leaves, wiry, 1-2-flowered. Flowers small, resupinate, yellowish-white to yellowish-green. Floral bracts small. Pedicellate ovary slender, terete. Sepals and petals subsimilar, lanceolate, acute to acuminate. Lip ovatelanceolate to elliptic with acuminate apex, cochleate, canaliculate, thin-textured. Spur filiform, straight, somewhat swollen at the apex, with narrow entrance.

The section Acaulia has been described by Garay (1973) to accomodate the species of the section Boryangraecum with 1-2-flowered inflorescence. Garay (1973) agreed with Schlechter (1918), who considered 1-flowered inflorescence to be a mere state of reduction from the several-flowered condition. The species of both sections, Acaulia and Boryangraceum, differ not only in the number of flowers per inflorescence, but also in the length and form of the spur. Acaulia comprises species with filiform, elongate spur, and Boryangraecum - with relatively short spur, hardly exceeding pedicellate ovary, which is swollen and blunt at the apex. In our opinion, these differences indicate different pollination syndrome.

Five species constitute this genus.

Hermansia brachyrhopalon (Schltr.) Szlach., Mytnik \& Grochocka, comb. nov.

B a si on ym: Angraecum brachyrhopalon Schltr., Repert. Spec. Nov. Regni Veg. Beih. 33: 336. 1925.

Hermansia chaetopoda (Schltr.) Szlach., Mytnik \& Grochocka, comb. nov.

B a si o ny m: Angraecum chaetopodum Schltr., Repert. Spec. Nov. Regni Veg. Beih. 33: 336. 1925.
Hermansia pergracile (Schltr.) Szlach., Mytnik \& Grochocka, comb. nov.

B a s i o ny m: Angraecum pergracile Schltr., Repert. Spec. Nov. Regni Veg. Beih. 33: 337. 1925.

Hermansia rhynchoglossa (Schltr.) Szlach., Mytnik \& Grochocka, comb. nov.

B a s i onym: Angraecum rhynchoglossum Schltr., Repert. Spec. Nov. Regni Veg. Beih. 33: 339. 1925.

Hermansia setipes (Schltr.) Szlach., Mytnik \& Grochocka, comb. nov.

B a si o ny m: Angraecum setipes Schltr., Repert. Spec. Nov. Regni Veg. Beih. 33: 340. 1925.

10. Humblotiangraecum (Schltr.) Szlach., Mytnik \& Grochocka, stat. et gen. nov.

B a s i on y m: Angraecum Bory sect. Humblotiangraecum Schltr., Repert. Sp. Nov. Regni Veg., Beih. 33: 310. 1925; G e ne rity pe: Aeranthes leonis Rchb.f. [三 Humblotiangraecum leonis (Rchb.f.) Szlach., Mytnik \& Grochocka].

Plants almost stemless, with arrested internodes. Leaves thick, fleshy, equitant, falcate, basally imbricating. Inflorescence few-flowered. Flowers large, showy, white, resupinate. Floral bracts prominent, amplexicaul. Pedicellate ovary slender, elongate. Sepals and petals subsimilar, lanceolate or similar, acute. Lip large, elliptic, concave, funnel-shaped in the lower half, keeled, acuminate towards the apex. Spur long, prominent, filiform, attenuate towards the apex, orifice spacious, broad.

The genus includes a few species which are easily distinguishable from all other Angraecinae by their peculiar habit, i.e., abbreviated internodes of the stem, equitant leaves, which basally are usually imbricating, and broad spur orifice. The species of Humblotiangraecum and Rudolfangraecum are intermixed on the phylogenetic tree presented here. However, we decided to keep them separately based on the habit characters.

Humblotiangraecum aloifolium (Hermans \& P.J.Cribb) Szlach., Mytnik \& Grochocka, comb. nov.

B a s i o n y m: Angraecum aloifolium Hermans \& P. J. Cribb, Orchid Rev. 105: 108 (1997).

Humblotiangraecum clareae (Hermans, la Croix \& P. J. Cribb) Szlach., Mytnik \& Grochocka, comb. nov. B a s i o n y m: Angraecum clareae Hermans, la Croix \& P. J. Cribb, Orchid Rev. 109: 43. 2001.

Humblotiangraecum equitans (Schltr.) Szlach., Mytnik \& Grochocka, comb. nov.

B a s i o n y m: Angraecum equitans Schltr. Beih. Bot. Centralbl. 34(2): 339. 1916.

Humblotiangraecum leonis (André) Szlach., Mytnik \& Grochocka, comb. nov.

B a s i o n y m: Aeranthes leonis Rchb. f., Gard. Chron., n. s., 23: 726. 1885. 
S y n o n y m: Angraecum leonis (Rchb. f.) André, Rev. Hort. 57: 294. 1885.

Humblotiangraecum potamophilum (Schltr.) Szlach., Mytnik \& Grochocka, comb. nov.

B a s i o n y m: Angraecum potamophilum Schltr. Ann. Mus. Colon. Marseille, sér. 3, 1: 199, t. 23. 1913.

11. Lemurangis (Garay) Szlach., Mytnik \& Grochocka, stat. nov.

B a s i o ny m: Angraecum Bory sect. Lemurangis Garay, Kew Bull. 28(3): 501. 1973; G e ne ri ty pe : Macroplectrum madagascariense Finet. $\equiv$ Angraecum madagascariense (Finet) Schltr. [三 Lemurangis madagascariensis (Finet) Szlach., Mytnik \& Grochocka].

Plants small. Stem elongate, leafy. Leaves oblong to ligulate, rather thick, fleshy, unequally bilobed at the apex, often falcately curved. Inflorescence usually 1-5-flowered, occasionally 1-flowered, mostly shorter than leaves, more or less fractiflex. Flowers tiny or small, nonresupinate, greenish, yellowish or whittish, often diaphanous. Pedicellate ovary short. Sepals and petals dissimilar, acute. Lip lanceolateovate to broadly lanceolate, acute to acuminate, concave at the base, canaliculate. Spur cylindrical or saccate, blunt, usually shorter than pedicel and ovary. Viscidium single, transversely elliptic, tegula single, ligulate.

Molecular analyses clearly indicate that the genus is sister to Lemurorchis and Angraecum and together form a monophyletic group. The species of the last two genera constituing this clade usually produce elongate, many-flowered inflorescence. The exception are species of Lemurangis which flowers are born on 1-5-flowered raceme. All members of this group carry pollinia attached to single tegula and viscidium.

Lemurangis includes nine species.

Lemurangis alleizettei (Schltr.) Szlach., Mytnik \& Grochocka, comb. nov.

B a s i o n y : Angraecum alleizettei Schltr., Repert. Spec. Nov. Regni Veg. 18: 325. 1922.

Lemurangis costata (Frapp. ex Cordem.) Szlach., Mytnik \& Grochocka, comb. nov.

B a si o n y m: Angraecum costatum Frapp. ex Cordem., Fl. Réunion: 211. 1895.

Lemurangis decaryana (H. Perrier) Szlach., Mytnik \& Grochocka, comb. nov.

B a s i o n y : Angraecum decaryanum H. Perrier, Notul. Syst. (Paris) 7: 129. 1938.

Lemurangis falcifolia (Bosser) Szlach., Mytnik \& Grochocka, comb. nov.

B a si o n y m: Angraecum falcifolium Bosser, Adansonia, n.s., 10: 104. 1970.

Lemurangis floribunda (Bosser) Szlach., Mytnik \& Grochocka, comb. nov.
B a s i o n y m : Angraecum floribundum Bosser, Adansonia, n.s., 10: 102. 1970.

Lemurangis humile (Summerh.) Szlach., Mytnik \& Grochocka, comb. nov.

B a s i on y m: Angraecum humile Summerh., Kew Bull. 13: 269. 1958.

Lemurangis longinoda (Frapp. ex Cordem.) Szlach., Mytnik \& Grochocka, comb. nov.

$\mathrm{B}$ a s i o n y m: Angraecum longinode Frapp. ex Cordem., Fl. Réunion: 210. 1895.

Lemurangis madagascariensis (Schltr.) Szlach., Mytnik \& Grochocka, comb. nov.

$\mathrm{B}$ a s i o n y m: Macroplectrum madagascariense Finet, Bull. Soc. Bot. France 54(9): 25. 1907. 三Angraecum madagascariense (Finet) Schltr., Beih. Bot. Centralbl. 36(2): 162. 1918.

Lemurangis pseudopetiolata (Frapp. ex Cordem.) Szlach., Mytnik \& Grochocka, comb. nov.

B a s i onym: Angraecum pseudopetiolatum Frapp. ex Cordem., Fl. Réunion: 207. 1895.

\section{Lepervenchea Cordem.}

Rev. Gen. Bot. 11: 415.1899; G e n e r i t y p e: Angraecum tenuifolium Frapp. ex Cordem. [三 Lepervenchea tenuifolia (Frapp. ex Cordem.) Cordem.].

Stem prominent, elongate. Leaves numerous, ligulate to linear, unequally bilobed at the apex, sometimes falcately curved. Inflorescence as long as or longer than leaves, racemose, rachis somewhat flexuos. Flowers small, resupinate, thin in texture, subdiaphanous. Floral bracts inconspicuous. Pedicellate ovary terete. Sepals and petals dissimilar, acute. Lip subcordate to oblong-lanceolate, more or less acuminate apically, occasionally obscurely 3-lobed, cochleate, ecallose. Spur relatively short, hardly exceeding pedicellate ovary, usually much shorter, cylindrical to saccate, blunt, straight. Pollinaria double.

Considering the habit, the species of Lepervenchea may be confused with Gomphocentrum and Lemurangis. Due to the double pollinaria, the species of Lepervenchea are similar to Gomphocentrum, but both genera differ in the spur form. In Gomphocentrum the spur is narrowly cylindrical, adapted to penetration by insect's long proboscis, whereas the spur in Lepervenchea is short and rather spacious. Basing on the spur and flower morphology, we can speculate that both Lepervenchea and Lemurangis exploit the same group of insects as pollinators. However, both genera are easily distinguishable one from another by different number of pollinaria produced in the flower, that is, single in Lemurangis and double in Lepervenchea.

The genus includes seven species.

Lepervenchea appendiculoides (Schltr.) Szlach., Mytnik \& Grochocka, comb. nov.

B a sionym: Angraecum appendiculoides Schltr., Repert. Spec. Nov. Regni Veg. 18: 325. 1922. 
Lepervenchea caricifolia (H. Perrier) Szlach., Mytnik \& Grochocka, comb. nov.

B a si onym: Angraecum caricifolium H. Perrier, Notul. Syst. (Paris) 7: 128. 1938.

Lepervenchea montana (Piers) Szlach., Mytnik \& Grochocka, comb. nov.

B a s i o n y m: Angraecum montanum Piers, Orchids E. Afr.: 244. 1968.

Lepervenchea musculifera (H. Perrier) Szlach., Mytnik \& Grochocka, comb. nov.

B a si o ny m: Angraecum musculiferum H. Perrier, Notul. Syst. (Paris) 7: 129. 1938.

Lepervenchea pauciramosa (Schltr.) Szlach., Mytnik \& Grochocka, comb. nov.

B a s i o nym: Angraecum pauciramosum Schltr., Repert. Spec. Nov. Regni Veg. Beih. 33: 350. 1925.

Lepervenchea tenuifolia (Frapp. ex Cordem.) Szlach., Mytnik \& Grochocka, comb. nov.

B a s i o n y m: Angraecum tenuifolium Frapp. ex Cordem., Fl. Réunion: 207. 1895.

Lepervenchea tenuispica (Schltr.) Szlach., Mytnik \& Grochocka, comb. nov.

B a s i o n y m: Angraecum tenuispica Schltr., Repert. Spec. Nov. Regni Veg. 15: 339. 1918.

13. Lesliegraecum Szlach., Mytnik \& Grochocka, stat. et nom. nov.

Replaced synonym: Mystacidium Lindl. sect. Nana Cordem., Rev. Gén. Bot. 11: 414. 1899; L e c to ty pe (Garay 1973: 502): Angraecum nanum Frapp. [三Lesliegraecum nanum (Frapp.) Szlach., Mytnik \& Grochocka]. 三Angraecum Bory sect. Nana (Cordem.) Garay, Kew Bull. 28(3): 502. 1973.

Etymology: Dedicated to Dr. Leslie Garay, an eminent American orchidologist.

Plants small to tiny with abbreviated stem. Leaves few to several, linear-lanceolate, usually falcate, thick. Inflorescence longer than leaves, laxly to subdensely few- to many-flowered, racemose. Flowers nonresupinate, tiny, inconspicuous, diaphanous, greenish, whittish, yellowish to pinkish. Floral bracts prominent. Pedicellate ovary short. Sepals and petals dissimilar, acute to acuminate. Lip ovate-lanceolate to oblong-ovate, acute to acuminate, concave at the base, canaliculate. Spur saccate to conical, blunt, short. Viscidium single oblong-elliptic, tegulae double, linear.

We do not have access to any material of this group appropriate to molecular analyses. Based on the plant habit and flower morphology, we can speculate that Lesliegraecum appears to be related to Lemurangis, however, a phylogenetic study is required. It is interesting to note that both flower arrangement in the inflorescence and general flower architecture in Lesliegraecum and Bolusiella Schltr. are alike, what may suggest an adaptation to similar pollination strategies.
The genus includes about 20 species.

Lesliegraecum andasibeense (H. Perrier) Szlach., Mytnik \& Grochocka, comb. nov.

$\mathrm{B}$ a s i ony m: Angraecum andasibeense H. Perrier, Notul. Syst. (Paris) 7: 124. 1938.

Lesliegraecum bemarivoense (Schltr.) Szlach., Mytnik \& Grochocka, comb. nov.

B a s i o n y m: Angraecum bemarivoense Schltr., Repert. Spec. Nov. Regni Veg. Beih. 33: 332. 1925.

Lesliegraecum burchellii (Rchb.f.) Szlach., Mytnik \& Grochocka, comb. nov.

B a si o n y m: Angraecum burchellii Rchb.f., Flora 50: 117.1867.

Lesliegraecum chamaeanthus (Schltr.) Szlach., Mytnik \& Grochocka, comb. nov.

B a s i o n y m: Angraecum chamaeanthus Schltr., Bot. Jahrb. Syst. 53: 604. 1915.

Lesliegraecum decipiens (Summerh.) Szlach., Mytnik \& Grochocka, comb. nov.

B a s i o n y m: Angraecum decipiens Summerh., Kew Bull. 20: 189. 1966.

Lesliegraecum microcharis (Schltr.) Szlach., Mytnik \& Grochocka, comb. nov.

B a s i o n y m: Angraecum microcharis Schltr., Repert. Spec. Nov. Regni Veg. Beih. 33: 333. 1925.

Lesliegraecum minus (Summerh.) Szlach., Mytnik \& Grochocka, comb. nov.

B a s i onym: Angraecum minus Summerh., Kew Bull. 13: 264. 1958.

Lesliegraecum minutum (Frapp. ex Cordem.) Szlach., Mytnik \& Grochocka, comb. nov.

B a si onym: Angraecum minutum Frapp. ex Cordem., Fl. Réunion: 209. 1895.

Lesliegraecum muscicolum (H.Perrier) Szlach., Mytnik \& Grochocka, comb. nov.

B a s i onym: Angraecum muscicolum H.Perrier, Notul. Syst. (Paris) 7: 126. 1938.

Lesliegraecum nanum (Frapp. ex Cordem.) Szlach., Mytnik \& Grochocka, comb. nov.

B a s i o n y m: Angraecum nanum Frapp. ex Cordem., Fl. Réunion: 208. 1895.

Lesliegraecum oberonia (Finet) Szlach., Mytnik \& Grochocka, comb. nov.

B a s i on y m: Angraecum oberonia Finet, Bull. Soc. Bot. France 54(9): 10. 1907.

Lesliegraecum onivense (H. Perrier) Szlach., Mytnik \& Grochocka, comb. nov.

B a s i o n y m: Angraecum onivense H. Perrier, Notul. Syst. (Paris) 7: 122. 1938.

Lesliegraecum parvulum (Ayres ex S.Moore) Szlach., Mytnik \& Grochocka, comb. nov.

$\mathrm{B}$ as i o n y m: Angraecum parvulum Ayres ex $\mathrm{S}$. Moore in J. G. Baker, Fl. Mauritius: 357. 1877.

Lesliegraecum perhumile (H. Perrier) Szlach., Mytnik \& Grochocka, comb. nov. 
B a s i o n y m: Angraecum perhumile H. Perrier, Notul. Syst. (Paris) 7: 127. 1938.

Lesliegraecum perparvulum (H. Perrier) Szlach., Mytnik \& Grochocka, comb. nov.

$\mathrm{B}$ a s i o n y $\mathrm{m}$ : Angraecum perparvulum $\mathrm{H}$. Perrier, Notul. Syst. (Paris) 7: 123. 1938.

Lesliegraecum pusillum (Lindl.) Szlach., Mytnik \& Grochocka, comb. nov.

B a s i o n y m : Angraecum pusillum Lindl., Companion Bot. Mag. 2: 205. 1836.

Lesliegraecum salazianum (Cordem.) Szlach., Mytnik \& Grochocka, comb. nov.

B a si ony m: Mystacidium salazianum Cordem., Rev. Gén. Bot. 11: 423. 1899. 三 Angraecum salazianum (Cordem.) Schltr., Beih. Bot. Centralbl. 33(2): 427. 1915.

Lesliegraecum spicatum (Cordem.) Szlach., Mytnik \& Grochocka, comb. nov

B a s i o n y m: Mystacidium spicatum Cordem., Rev. Gén. Bot. 11: 423. 1899. 三Angraecum spicatum (Cordem.) Schltr., Beih. Bot. Centralbl. 33(2): 437. 1915.

Lesliegraecum tenellum (Ridl.) Szlach., Mytnik \& Grochocka, comb. nov.

B a s i o n y m: Mystacidium tenellum Ridl., J. Linn. Soc., Bot. 21: 489. 1885. 三Angraecum tenellum (Ridl.) Schltr., Beih. Bot. Centralbl. 33(2): 438. 1915.

Lesliegraecum viridiflorum (Cordem.) Szlach., Mytnik \& Grochocka, comb. nov.

B a s i o n y m : Angraecum viridiflorum Cordem., Rev. Gén. Bot. 11: 9. 1899.

\section{Macroplectrum Pfitzer}

in Engl. \& Prantl., Nat. Pflanzenfam. 2(6): 208. 1889; Ge neritype: Angraecum sesquipedale Thouars [三 Macroplectrum sesquipedale (Thouars) Pfitzer].

Stem erect, occasionally branching, stout. Leaves ligulate, unequally bilobed apically, leathery, stout, usually gathered at the apex of the stem. Inflorescence few-flowered, racemose. Flowers large, showy, white, strongly fragrant, resupinate. Pedicellate ovary long, conspicuous. Sepals and petals subsimilar, attenuate towards apex, acute, spread. Lip large, longer than wide, canaliculate, ecallose, apically long-acuminate. Spur very conspicuous, filiform from narrowly conical base, acute. Tegula and viscidium separated, double, hence, two pollinaria are produced.

The genus includes very spectacular species. It was originally described by Pfitzer (1889) as a monotypic genus. Later his concept of the genus has been extended by Finet (1907), who included in Macroplectrum several species from various sections.

Macroplectrum includes only three species restricted in their distribution to Madagascar.

Macroplectrum bosseri (Senghas) Szlach., Mytnik \& Grochocka, comb. nov.
B a s i on y m: Angraecum bosseri Senghas, Die Orchidee 24: 193. 1973. EAngraecum sesquipedale Thouars var. angustifolium Bosser \& Morat, Adansonia, n.s., 12: 77.1972.

Macroplectrum sesquipedale (Thouars) Szlach., Mytnik \& Grochocka, comb. nov.

B a s i o n y m: Angraecum sesquipedale Thouars, Hist. Orchid.: 66. 1822.

Macroplectrum sororium (Schltr.) Szlach., Mytnik \& Grochocka, comb. nov.

B a s i o ny m: Angraecum sororium Schltr., Repert. Spec. Nov. Regni Veg., Beih. 33: 360. 1925.

15. Pectinariella Szlach., Mytnik \& Grochocka, stat. et. nom. nov.

Replaced synonym: Mystacidium Lindl. sect. Pectinaria Benth. in Benth. \& Hook.f., Gen. Pl. 3: 585. 1883; Ge ne ritype: Angraecum pectinatum Thouars [三Pectinariella pectinata (Thouars)]. $\equiv A n$ graecum Bory sect. Pectinaria (Benth.) Schltr., Beih. Bot. Centralbl. 36(2): 157. 1918, non Pectinaria Cordem., Rev. Gen. Bot. 11: 412. 1899, non Pectinaria Bernh., 1800 (Apiaceae); non Pectinaria Haw., 1819 (Apocynaceae); non Pectinaria (Benth.) Hack., 1887 (Poaceae).

E t y m o log y : -ella-similar to Pectinaria; name of one of the sections of Angraecum. Raising the name Pectinaria to the generic rank is illegitimate due to ICN.

Stem long, usually pendent, branching, loosely leafy, internodes elongate. Leaves alternate, fleshy, linear to linear-lanceolate, shortly acuminate, never equitant, petiole twisted. Inflorescence always single-flowered. Flowers tiny, subresupinate, white, scented. Floral bracts small, amplexicaul. Pedicellate ovary short. Sepals and petals subsimilar, obtuse to subobtuse at the apex. Lip ligulate, oblong to transversely elliptic, canaliculate, ecallose. Spur cylindrical to clavate, subequal in length to the ovary, sometimes shorter, occasionally longer than pedicellate ovary, often swollen and blunt at the apex, orifice usually narrow. Pollinia pyriform, tegula greatly reduced, viscidium elliptic, single.

The genus is easily distinguishable from all other Angraecinae by its peculiar habit, that is fleshy leaves, basally twisted with almost sessile flowers forming single-flowered inflorescence and ecallose lip. Pectinariella is embedded in the clade comprising Angraecoides and Eichlerangraceum. But the flower size and morphology indicate that they exploit different pollinators and evolved under strong pollinator's pressure.

Pectinariella dasycarpa (Schltr.) Szlach., Mytnik \& Grochocka, comb. nov.

B a s i o n y m: Angraecum dasycarpum Schltr., Repert. Spec. Nov. Regni Veg. 15: 337. 1918.

Pectinariella doratophylla (Summerh.) Szlach., Mytnik \& Grochocka, comb. nov. 
B a s i o n y m: Angraecum doratophyllum Summerh., Bull. Misc. Inform. Kew 1937: 465. 1937.

Pectinariella gabonense (Summerh.) Szlach., Mytnik \& Grochocka, comb. nov.

$\mathrm{B}$ a s i o n y m : Angraecum gabonense Summerh., Kew Bull. 8: 587. 1953 (publ. 1954).

Pectinariella hermannii (Cordem.) Szlach., Mytnik \& Grochocka, comb. nov.

B a s i o n y m: Mystacidium hermannii Cordem., Rev. Gén. Bot. 11: 421. 1899. 三Angraecum hermannii (Cordem.) Schltr., Beih. Bot. Centralbl. 33(2): 434. 1915.

Pectinariella humblotiana (Finet.) Szlach., Mytnik \& Grochocka, comb. nov.

B a s i o nym: Angraecum humblotianum (Finet) Schltr., Beih. Bot. Centralbl. 33(2): 434. 1915.

Pectinariella pectinata (Thouars.) Szlach., Mytnik \& Grochocka, comb. nov.

B a s i o n y m: Angraecum pectinatum Thouars, Hist. Orchid.: 51.1822.

Pectinariella pungens (Schltr.) Szlach., Mytnik \& Grochocka, comb. nov.

B a s i o n y m: Angraecum pungens Schltr., Bot. Jahrb. Syst. 38: 163. 1906.

Pectinariella subulata (Lindl.) Szlach., Mytnik \& Grochocka, comb. nov.

B a s i o n y m : Angraecum subulatum Lindl., Companion Bot. Mag. 2: 206. 1836.

16. Perrierangraecum (Schltr.) Szlach., Mytnik \& Grochocka, stat. et gen. nov.

B a s i o n y m: Angraecum Bory sect. Perrierangraecum Schltr., Repert. Sp. Nov. Regni Veg., Beih. 33: 309. 1925; G e n e ri ty p e (Garay 1973: 499): Angraecum triquetrum Thouars [ Perrierangraecum triquetrum (Thouars) Szlach., Mytnik \& Grochocka].

Plants with usually erect, apically leafy stem. Leaves linear, leathery, occasionally thick, unequally bilobed at the apex. Inflorescence usually 1-flowered, occasionally few-flowered. Peduncle completely covered with 3-4 compressed sheaths. Flowers relatively large, showy, resupinate. Pedicellate ovary often triquetros. Sepals and petals subsimilar, apically attenuate, longacuminate. Lip distinctly larger than other segments, simple, ovate-lanceolate to broadly-lanceolate, attenuate to apex, long-acuminate, ecallose, canaliculate. Spur long, filiform, acute with very narrow base. Tegula greatly reduced, viscidia double, separated, hence, two pollinaria.

The genus, as proposed here, includes the species classified mostly within the section Perrierangraecum so far. They may be confused with the species of Macroplectrum, because of similar habit, however the representatives of the latter genus are generally smaller plants. The results of our molecular analyses clearly indicate that both groups are only distantly related.
Their similarity may result from an exploitation of the same group of pollinators. Both genera can be separated based on the number of flowers in the inflorescence and the type of floral bracts.

Perrierangraecum includes 34 species.

Perrierangraecum ambrense (H. Perrier) Szlach., Mytnik \& Grochocka, comb. nov.

B a s i o n y m: Angraecum ambrense H. Perrier, Notul. Syst. (Paris) 7: 118. 1938.

Perrierangraecum ankeranense (H. Perrier) Szlach., Mytnik \& Grochocka, comb. nov.

$\mathrm{B}$ a si o ny m: Angraecum ankeranense H. Perrier, Notul. Syst. (Paris) 7: 115. 1938.

Perrierangraecum bicallosum (H. Perrier) Szlach., Mytnik \& Grochocka, comb. nov.

B a s i o n y m: Angraecum bicallosum H. Perrier, Notul. Syst. (Paris) 7: 111. 1938.

Perrierangraecum breve (Schltr.) Szlach., Mytnik \& Grochocka, comb. nov.

B a s i o n y m: Angraecum breve Schltr., Repert. Spec. Nov. Regni Veg. Beih. 33: 324. 1925.

Perrierangraecum chimanimaniense (G. Will.) Szlach., Mytnik \& Grochocka, comb. nov.

$\mathrm{B}$ a s i on y m: Angraecum chimanimaniense G. Will., Kew Bull. 51(3): 557 (1996). 1996.

Perrierangraecum compactum (Schltr.) Szlach., Mytnik \& Grochocka, comb. nov.

B a s i o n y m: Angraecum compactum Schltr., Beih. Bot. Centralbl. 34(2): 339. 1916.

Perrierangraecum compressicaule (H. Perrier) Szlach., Mytnik \& Grochocka, comb. nov.

B a s i on y m: Angraecum compressicaule H. Perrier, Notul. Syst. (Paris) 7: 118. 1938.

Perrierangraecum cucullatum (Thouars) Szlach., Mytnik \& Grochocka, comb. nov.

B a s i on y m: Angraecum cucullatum Thouars, Hist. Orchid.: 48. 1822.

Perrierangraecum curnowianum (Rchb. f.) Szlach., Mytnik \& Grochocka, comb. nov.

B a s i o n y m: Aeranthes curnowiana Rchb. f., Gard. Chron., n.s., 19: 306. 1883. EAngraecum curnowianum (Rchb. f.) T. Durand \& Schinz, Consp. Fl. Afric. 5: 41. 1894.

Perrierangraecum curvicalcar (Schltr.) Szlach., Mytnik \& Grochocka, comb. nov.

B a s i o n y m: Angraecum curvicalcar Schltr., Repert. Spec. Nov. Regni Veg. Beih. 33: 325. 1925.

Perrierangraecum didieri (Baill. ex Finet) Szlach., Mytnik \& Grochocka, comb. nov.

$\mathrm{B}$ a s i o n y $\mathrm{m}$ : Macroplectrum didieri Baill. ex Finet, Bull. Soc. Bot. France 54(9): 28. 1907. $\equiv$ Angraecum didieri (Baill. ex Finet) Schltr., Beih. Bot. Centralbl. 33(2): 433.1915.

Perrierangraecum divaricatum (Frapp. ex Cordem..) Szlach., Mytnik \& Grochocka, comb. nov. 
Bas i onym: Angraecum divaricatum Frapp. ex Cordem., Fl. Réunion: 177. 1895.

Perrierangraecum drouhardii (H. Perrier) Szlach., Mytnik \& Grochocka, comb. nov.

$\mathrm{B}$ a s i o n y m: Angraecum drouhardii H. Perrier, Notul. Syst. (Paris) 7: 117. 1938.

Perrierangraecum dryadum (Schltr.) Szlach., Mytnik \& Grochocka, comb. nov.

B a si ony m: Angraecum dryadum Schltr., Repert. Spec. Nov. Regni Veg., Beih. 33: 326. 1925.

Perrierangraecum elephantinum (Schltr.) Szlach., Mytnik \& Grochocka, comb. nov.

B a si o n y m: Angraecum elephantinum Schltr., Notizbl. Bot. Gart. Berlin-Dahlem 7: 330. 1919.

Perrierangraecum imerinense (Schltr.) Szlach., Mytnik \& Grochocka, comb. nov.

B a s i o n y m : Angraecum imerinense Schltr., Repert. Spec. Nov. Regni Veg., Beih. 33: 328. 1925.

Perrierangraecum kranzlinianum (H. Perrier) Szlach., Mytnik \& Grochocka, comb. nov.

B a si o n y m: Angraecum kranzlinianum H. Perrier, Fl. Madag., Orchid. 4(2): 276. 1941.

Perrierangraecum lecomtei (H. Perrier) Szlach., Mytnik \& Grochocka, comb. nov.

B a s i o n y m: Angraecum lecomtei H. Perrier, Notul. Syst. (Paris) 7: 119. 1938.

Perrierangraecum letouzeyi (Bosser) Szlach., Mytnik \& Grochocka, comb. nov.

B a s i o n y m: Angraecum letouzeyi Bosser, Bull. Mus. Natl. Hist. Nat., B, Adansonia, Botanique Phytochimie 11(4): 374, f. 3. 1990.

Perrierangraecum liliodorum (Frapp. ex Cordem.) Szlach., Mytnik \& Grochocka, comb. nov.

B a s i o n y m: Angraecum liliodorum Frapp. ex Cordem., Fl. Réunion: 198. 1895.

Perrierangraecum litorale (Schltr.) Szlach., Mytnik \& Grochocka, comb. nov.

B a s i o n y m: Angraecum litorale Schltr., Repert. Spec. Nov. Regni Veg. Beih. 33: 327. 1925.

Perrierangraecum longicaule (H. Perrier) Szlach., Mytnik \& Grochocka, comb. nov.

$\mathrm{B}$ a s i o n y : Angraecum longicaule H. Perrier, Mém. Inst. Sci. Madagascar, Sér. B, Biol. Vég. 6: 266. 1955.

Perrierangraecum obesum (H.Perrier) Szlach., Mytnik \& Grochocka, comb. nov.

B a s i o n y m: Angraecum obesum H.Perrier, Notul. Syst. (Paris) 7: 114. 1938.

Perrierangraecum oblongifolium (Toilliez-Genoud \& Bosser) Szlach., Mytnik \& Grochocka, comb. nov.

B a s i o n y m: Angraecum oblongifolium ToilliezGenoud \& Bosser, Nat. Malgache 12: 13. 1960.

Perrierangraecum palmicolum (Bosser) Szlach., Mytnik \& Grochocka, comb. nov.
B a s i o ny m: Angraecum palmicolum Bosser, Bull. Mus. Natl. Hist. Nat., B, Adansonia, Botanique Phytochimie 11: 376, f. 4. 1990.

Perrierangraecum praestans (Schltr.) Szlach., Mytnik \& Grochocka, comb. nov.

B a si onym: Angraecum praestans Schltr., Ann. Mus. Colon. Marseille, sér. 3, 1: 200, t. 21. 1913.

Perrierangraecum protensum (Schltr.) Szlach., Mytnik \& Grochocka, comb. nov.

B a s i o n y m: Angraecum protensum Schltr., Repert. Spec. Nov. Regni Veg. Beih. 33: 358. 1925.

Perrierangraecum pseudodidieri (H. Perrier) Szlach., Mytnik \& Grochocka, comb. nov.

B a s i ony m: Angraecum pseudodidieri H. Perrier, Notul. Syst. (Paris) 7: 113. 1937.

Perrierangraecum rigidifolium (H. Perrier) Szlach., Mytnik \& Grochocka, comb. nov.

$\mathrm{B}$ a s i o nym: Angraecum rigidifolium $\mathrm{H}$. Perrier, Notul. Syst. (Paris) 7: 116. 1938.

Perrierangraecum rutenbergianum (Kraenzl.)

Szlach., Mytnik \& Grochocka, comb. nov.

B a s i ony m: Angraecum rutenbergianum Kraenzl., Abh. Naturwiss. Vereine Bremen 7: 257. 1882.

Perrierangraecum sambiranoense (Schltr.) Szlach., Mytnik \& Grochocka, comb. nov.

B a si onym: Angraecum sambiranoense Schltr., Repert. Spec. Nov. Regni Veg., Beih. 33: 329. 1925.

Perrierangraecum stella-africae (P. J. Cribb)

Szlach., Mytnik \& Grochocka, comb. nov.

B a s i onym: Angraecum stella-africae P.J.Cribb, Malawi Orch. 1: 134. 1983.

Perrierangraecum triquetrum (Thouars) Szlach., Mytnik \& Grochocka, comb. nov.

B a s i o ny m: Angraecum triquetrum Thouars, Hist. Orchid.: 49. 1822.

Perrierangraecum urschianum (Toill.-Gen. \& Bosser) Szlach., Mytnik \& Grochocka, comb. nov.

B a s i o n y m: Angraecum urschianum Toill.-Gen. \& Bosser, Adansonia, n.s., 1: 101. 1961.

17. Pseudojumellea (Schltr.) Szlach., Mytnik \& Grochocka, stat. et gen. nov.

B a s i on y m: Angraecum Bory sect. Pseudojumellea Schltr., Beih. Bot. Centralbl. 36(2): 157. 1918;

L e c t ot y p e (Garay 1973: 500): Angraecum mauritianum (Poir.) Frapp. [三 Pseudojumellea mauritiana (Poir.) Szlach., Mytnik \& Grochocka].

= Angraecum Bory sect. Filangis Garay, Kew Bull. 28(3): 500. 1973; TYPE SPECIES: Angraecum filicornu Thouars

Plants with elongate stem with prominent internodes. Leaves linear to ligulate, occasionally oblong-elliptic, conduplicate, unequally bilobed at apex, sheaths tightly adnate to the stem. Inflorescence always single-flowered. Peduncle prominent, slender, covered at base with 
1-2 adpressed sheaths. Flowers rather large to mediumsized, resupinate, showy. Sepals and petals subsimilar, widely spread, giving the flowers a star appearence. Lip oblong-ovate to ovate-lanceolate, widest at the base, attenuate towards the apex, acute, with more or less conspicuous keel in the basal part. Spur very long, slender, filiform, acute, narrow at the base. Viscidia double, each oblong-elliptic, thin, tegulae double filiform.

We did not have an access to any DNA materials of the Pseudojumellea species. Therefore, our conclusions are based on the detailed morphological studies only. These species of the two Garay's (1973) sections, that is Filangis and Pseudojumellea, are not separable one from another. According to Garay (1973), the key character distinguishing the two taxa is the length of peduncle, which should be short in most Filangis species and usually long and prominent in Pseudojumellea. In our opinion the taxonomic value and constancy of this feature is questionable.

The species of the genus, as a generic name suggests, are like those of Jumellea, but the lip base is broad and overlaps the gynostemium, in contrast to Jumellea, in which the lip is narrow at the base and does not overlap the gynostemium. The Pseudojumellea species might be confused with those of Rudolfangraecum, but the former is characterized by a narrow spur entrance and presence of two separate pollinaria produced in each gynostemium. Rudolfangraecum possesses broad spur entrance and single pollinarium, that is, pollinia are attached to V-shaped tegula connected to a single viscidium. This differences could emerge as an adaptation to different pollination strategies.

Pseudojumellea is represented by eleven species.

Pseudojumellea amplexicaule (Toill.-Gen. \& Bosser) Szlach., Mytnik \& Grochocka, comb. nov. B a si on y m: Angraecum amplexicaule Toill.-Gen. \& Bosser, Nat. Malgache 12: 11. 1961.

Pseudojumellea cornigera (Cordem.) Szlach., Mytnik \& Grochocka, comb. nov.

B a s i o n y m: Angraecum cornigerum Cordem., Rev. Gén. Bot. 11: 418. 1899.

Pseudojumellea coutrixii (Bosser) Szlach., Mytnik \& Grochocka, comb. nov.

B a s i o n y m: Angraecum coutrixii Bosser, Adansonia, n. s., 10: 107. 1970.

Pseudojumellea filicornu (Thouars) Szlach., Mytnik \& Grochocka, comb. nov.

B a s i o nym: Angraecum filicornu Thouars, Hist. Orchid.: 52. 1822.

Pseudojumellea florulenta (Rchb.f.) Szlach., Mytnik \& Grochocka, comb. nov.

B a s i o n y m: Angraecum florulentum Rchb. f., Gard. Chron. I. 787. 1885.

Pseudojumellea implicata (Thouars) Szlach., Mytnik \& Grochocka, comb. nov.
B a s i o n y m: Angraecum implicatum Thouars, Hist. Orchid.: 58. 1822.

Pseudojumellea mauritiana (Poir.) Szlach., Mytnik \& Grochocka, comb. nov.

B a s i ony m: Orchis mauritiana Poir. in J. B. A.M. de Lamarck, Encycl. 4: 601. 1798. 三Angraecum mauritianum (Poir.) Frapp., Cat. Orchid. Reunion: 13. 1889.

Pseudojumellea meirax (Rchb. f.) Szlach., Mytnik \& Grochocka, comb. nov.

B a si o n y m: Aeranthes meirax Rchb. f., Flora 68: 540. 1885. $\equiv$ Angraecum meirax (Rchb. f.) H. Perrier, Notul. Syst. (Paris) 7: 120. 1938.

Pseudojumellea melanosticta (Schltr.) Szlach., Mytnik \& Grochocka, comb. nov.

B a s i o nym: Angraecum melanostictum Schltr., Repert. Spec. Nov. Regni Veg. 15: 338. 1918.

Pseudojumellea moratii (Bosser) Szlach., Mytnik \& Grochocka, comb. nov.

B a s i o n y m: Angraecum moratii Bosser, Adansonia, n.s., 10: 106. 1970.

Pseudojumellea trichoplectron (Rchb.f.) Szlach., Mytnik \& Grochocka, comb. nov.

B a s i o n y m: Aeranthes trichoplectron Rchb.f., Gard. Chron. 1888: 264. 1888. $\equiv$ Angraecum trichoplectron (Rchb.f.) Schltr., Beih. Bot. Centralbl. 33(2): 348. 1915.

18. Rudolfangraecum Szlach., Mytnik \& Grochocka, gen. nov.

Stem elongate or relatively short. Leaves conduplicate, ligulate to linear, unequally bilobed at the apex, leathery to fleshy. Inflorescence 1-2-flowered. Flowers resupinate, showy, scenty. Lip large, unlobed, long-acuminate apically, ecallose. Spur elongate, infundibuliform basally, filiform above. Viscidia double, but connate marginally to one another, forming a single, very large, more or less reniform structure, tegula much smaller, single.

G e n e r i t y p e: Angraecum magdalenae Schltr. \& H. Perrier [ $[$ Rudolfangraecum magdalenae (Schltr. \& H. Perrier) Szlach., Mytnik \& Grochocka].

E t y m o l o g y: Dedicated to Dr. Rudolf Schlechter, a founder of modern orchidology.

Undoubtedly, the species of this genus are closely related to Humblotiangraecum, with which they share general flower structure, but are distinguished from the latter by the habit. They produce more or less elongate stem with conduplicate, more or less leathery leaves.

The species of this genus can be misidentified with the Perrierangraecum species, because they are similar in habit. The clear border line between two genera is the mouth of the spur, in Perrierangraceum it is narrow from the base, in Rudolfangraecum it is infundibuliform.

The genus includes three species.

Rudolfangraecum dollii (Senghas) Szlach., Mytnik \& Grochocka, comb. nov. 
B a si onym: Angraecum dollii Senghas, J. Orchideenfreund 4: 16. 1997.

Rudolfangraecum magdalenae (Schltr. \& H. Perrier) Szlach., Mytnik \& Grochocka, comb. nov.

B a s i onym: Angraecum magdalenae Schltr. \& H.Perrier, Repert. Spec. Nov. Regni Veg. Beih. 33: 354. 1925.
Rudolfangraecum viguieri (Schltr.) Szlach., Mytnik \& Grochocka, comb. nov.

B a si ony m: Angraecum viguieri Schltr. Repert. Spec. Nov. Regni Veg. 18: 326. 1922.

\section{References}

Arends J. C., Van Der Burg W. J. \& Van Der Laan F. M. 1980. Notes on African orchids. In J. C. ARENDS \& H. C. D. DE WIT (eds.). Liber gratulatorius in honorem H. C. D. de Wit. pp. 449. H. Veenman \& Zonen, Wageningen, Netherlands.

Arends J. C. \& Van Der LaAn F. M. 1983. Cytotaxonomy of the monopodial orchids of the African and Malagasy regions. Genetica 62: 81-94.

Bentham G. 1881. Notes on Orchideae. J. Linn. Soc., Bot. 18: $281-360$.

CAMERON K. M. 2001. An expanded phylogenetic analysis of Orchidaceae using three plastid genes: rbcL, atpB, and psaB. Amer. J. Bot. 88: 104.

Carlsward B. S., Whitten W. M. \& Williams N. H. 2003. Molecular phylogenetics of neotropical leafless Angraecinae (Orchidaceae): reevaluation of generic concepts. Int. J. P1. Sci. 164: 43-51.

Carlsward B. S., Whitten M. W., Williams N. W. \& ByteBIER B. 2006. Molecular phylogenetics of Vandeae (Orchidaceae) and the evolution of leaflessness. Amer. J. Bot. 93: 770-786.

Chase M. W., Freudenstein J. V., Cameron K. M. \& Barrett R. L. 2003. DNA data and Orchidaceae systematics: a new phylogenetic classification. In K. W. DixON, S. P. Kell, R. L. Barrett \& P. J. Cribb (eds.). Orchid conservation, pp. 69-89. Natural History Publications, Kota Kinabalu, Malaysia.

Cribb P. J., Hermans J. \& Roberts D. L. 2007. Erasanthe (Orchidaceae, Epidendroideae, Vandeae, Aerangidinae), a new endemic orchid genus from Madagascar. Adansonia 29(1): 27-30.

Dolphin K., Belshaw R., Orme L. D. C. \& Ouicke D. L. J. 2000. Noise and Incongruence: Interpreting results of the Icongruence Length Difference Test. Molec. Phylogen. Evol. 17(3): 401-406.

DRESSLER R. L. 1981. The orchids: natural history and classification, pp. 153-159. Harvard University Press, Cambridge, Massachusetts, USA.

DRESSLER R. L. 1989. The vandoid orchids: a polyphyletic grade? Lindleyana 4: 89-93.

DressLeR R. L. 1993. Phylogeny and Classification of the Orchid Family, pp. 205-209. Dioscorides Press, Portland.
Dressler R. L. \& Dodson C. H. 1960. Classification and phylogeny in the Orchidaceae. Ann. Missouri Bot. Gard. 47: 25-68.

Farris J. S., Kallersjo M., Kluge A. G. \& Bult C. 1994. Testing significance of incongruence. Cladistics 10: 315-319.

Felsenstein J. 1985. Confidence limits on phylogenies: an approach using the bootstrap. Evolution 39: 783-791.

Fiтch W. M. 1971. Toward defining the course of evolution: minimum change for a specific tree topology. Syst. Zool. 20: 406-416.

Freudenstein J. V. \& Rasmussen F. N. 1999. What does morphology tell us about orchid relationships? A cladistic analysis. Amer. J. Bot. 86: 225-248.

Galtier N., Gouy M. \& Gautier C. 1996. Sea View and Phylo win, two graphic tools for sequence alignment and molecular phylogeny. CABIOS 12: 543-548.

GARAY L. A. 1960. On the origin of the Orchidaceae. Bot. Mus. Leafl., Harvard University 19: 57-95.

GARAY L. A. 1972. On the origin of the Orchidaceae II. Journal of the Arnold Arboretum 53: 202-215.

GARAY L. A. 1973. Systematics of the genus Angraecum (Orchidaceae). Kew Bull. 28: 495-516.

Grant V. 1985. Additional observations on temperate North American hawkmoth flowers. Bot. Gaz. 146: 517-520.

Haber W. A. \& Frankie G.W. 1989. A tropical hawkmoth community: Costa Rican dry forest Sphingidae. Biotropica 21: 155-172.

Johnson S. D. \& Steiner K. E. 2000. Generalization versus specialization in plant pollination systems. Trends Ecol. Evol. 15: 140-143.

Jones K. 1967. The chromosomes of orchids, II. Kew Bull. 21: 151-156.

Kelchner S. A. 2000. The evolution of non-coding chloroplast DNA and its apllication in plant systematics. Ann. Missouri Bot. Gard. 87(4): 482-498.

LindLEY J. 1835. The Genera and Species of Orchidaceous Plants, pp. 553. Ridgways. London.

Martins D. J \& Johnson S. D. 2007. Hawkmoth pollination of aerangoid orchids in Kenya, with special reference to nectar sugar concentration gradients in the floral spurs. Amer. J. Bot. 94: 650-659. 
Micheneau C., Fournel J. \& Pailler T. 2006. Bird pollination in an angraecoid orchid on Reunion Island (Mascarene Archipelago, Indian Ocean). Ann. Bot. 97: 965-974.

Micheneau C., Carlsward B. S., Fay M. F., Bytebier B., Pailler T. \& Chase M. W. 2008a. Phylogenetics and biogeography of Mascarene angraecoid orchids (Vandeae, Orchidaceae). Mol. Phylogenet. Evol. 46(3): 908-22.

Micheneau C, Fournel J, Gauvin-Bialecki A. \& Pailler T. 2008b. Auto-pollination in a long-spurred endemic orchid (Jumellea stenophylla) on Reunion Island (Mascarene Archipelago, Indian Ocean). P1. Syst. Evol. 272: 11-22.

Micheneau C., Fournel J., Warren B., Hugel S., BialeckiGauvin A., Pailler T., Stasberg D. \& Chase M. 2010. Orthoptera, a new order of pollinator. Ann. Bot. 105: 355-364.

Momose K., Yumoto T., Nagamitsu T., Kato M., Nagamasu H., Sakai S., Harrison R. D., Itioka T., Hamid A. A. \& INOUE T. 1998. Pollination biology in a lowland dipterocarp forest in Sarawak, Malaysia. 1. Characteristics of the plant-pollinator community in a lowland dipterocarp forest. Amer. J. Bot. 85: 1477-1501.

Nilsson L. A., Jonsson L., RAson L. \& RANDRIANJohany E. 1985. Monophily and pollination mechanisms in Angraecum arachnites Schltr. (Orchidaceae) in a guild of long-tongued hawk-moths (Sphingidae) in Madagascar. Biol. J. Linn. Soc. 26: 1-19.

NyLANDER J. A. A. 2004. MrModeltest v2. Program distributed by the author. Evolutionary Biology Centre, Uppsala University.

Pfitzer E. H. 1889. Orchidaceae. In: A. Engler \& K. Prantl (eds.). Die natürlichen Pflanzenfamilien 3: 52-220. Wilhelm Engelmann Verlag, Leipzig.

Reeves G., Chase M. W., Goldblatt P., Rudall P., Fay M. F., Cox A. V., Lejeune B. \& Souza-Chies T. 2001. Molecular systematics of Iridaceae: evidence from four plastid regions. Amer. J. Bot. 88: 2074-2087.

Ronquist F. \& Huelsenbeck J.P. 2003. MrBayes: Bayesian phylogenetic inference under mixed models. Bioinformatics 19: 1972-1974.

Salamin N., Chase M. W., Hodkinson T. R. \& Savolainen V. 2003. Assessing internal support with large phylogenetic DNA matrices. Mol. Phylogenet. Evol. 27: 528-539.

SChlechter R. 1918. Versuch einer naturlichen Neuordnung der afrikanischen agraekoiden Orchidaceen. Beih. Bot. Centralbl., Abt. 2. 36: 62-181.

Schlechter R. 1925. Orchidaceae Perrierianae. Fedde Rep. Beih. 33: 1-391.

Shaw J., Lickey E. B., Schilling E. E. \& Small R. L. 2007. Comparison of whole chloroplast genome sequences to choose noncoding regions for phylogenetic studies in angiosperms: the tortoise and the hare III. Amer. J. Bot. 94: 275-288.

Simmons M. P. \& Ochoterena H. 2000. Gaps as characters in sequence-based phylogenetic analyses. Syst. Biol. 49(2): 369-81.

Stewart J., Hermans J. \& Campbell B. 2006. Angraecoid Orchids: Species from the African Region. Timber Press, Portland, Oregon.

Summerhayes V. S. 1966. African Orchids: XXX. Kew Bull. 20: 165-199.

Sun Y., Skinner D. Z., Liang G. H. \& Hulbert S. H. 1994. Phylogenetic analysis of Sorghum and related taxa using internal transcribed spacers of nuclear ribosomal DNA. Theor. Appl. Genet. 89: 26-32.

Swofford D. L. 2003. PAUP*: phylogenetic analysis using parsimony (*and other methods), version $4.0 \mathrm{~b} 10$. Sinauer, Sunderland, Massachusetts, USA.

SzlachetKo D. L. 1995. Systema Orchidalium. Fragm. Florist. Geobot. Suppl. 3: 1-152.

Szlachetko D. L. 2003. Genera et species Orchidalium. 7. Vandeae. Ann. Bot. Fennici 40(1): 67-70.

Szlachetko D. L. \& Romowicz A. 2007. Dolabrifolia, un nouveau genre d'orchidees de l'alliance Angraecum. Richardiana 7(2): 53-54.

Taberlet P., Gielly L., Pautou G. \& Bouvet J. 1991. Universal primers for amplification of three non-coding regions of chloroplast DNA. Plant Mol. Biol. 17: 1105-1109.

Van Den Berg C., Goldman D. H., Freudenstein J. V., Pridgeon A. M., Cameron K. M. \& Chase M. W. 2005. An overview of the phylogenetic relationships within Epidendroideae inferred from multiple DNA regions and recircumscription of the Epidendreae and Arethuseae (Orchidaceae). Amer. J. Bot. 92: 613-624.

Wendel J. F. \& Doyle J. J. 1998. Phylogenetic incongruence: window into genome history and molecular evolution. In: D. E. Soltis, P. S. Soltis \& J. J. Doyle (eds.). Molecular systematics of plants II: DNA sequencing, pp. 265-296. Kluwer Academic, Boston, Massachusetts, USA.

White T. J., Bruns T., Lee S. \& Taylor J. W. 1990. Amplification and direct sequencing of fungal ribosomal DNA genes for phylogenetics. In: M. A. InNIs, D. H. Gelgard, J. J. Sninsky \& T. J. White (eds.). Protocols: A Guide to Methods and Application, pp. 315-322. New York: Academic Press.

WiENS J. J. 1998. Combining data sets with different phylogenetic histories. Syst. Biol. 47: 568-581. 